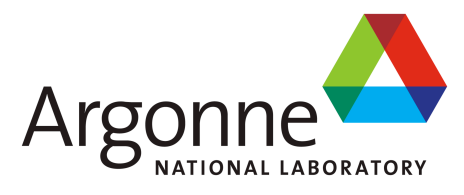

ANL-ARC-205

Report on Sodium Compatibility of Advanced Structural Materials

Nuclear Engineering Division 


\section{About Argonne National Laboratory}

Argonne is a U.S. Department of Energy laboratory managed by UChicago Argonne, LLC under contract DE-AC02-06CH11357. The Laboratory's main facility is outside Chicago, at 9700 South Cass Avenue, Argonne, Illinois 60439. For information about Argonne and its pioneering science and technology programs, see www.anl.gov.

\section{Availability of This Report}

This report is available, at no cost, at http://www.osti.gov/bridge. It is also available on paper to the U.S. Department of Energy and its contractors, for a processing fee, from:

U.S. Department of Energy

Office of Scientific and Technical Information

P.O. Box 62

Oak Ridge, TN 37831-0062

Phone (865) 576-8401

Fax (865) 576-5728

reports@adonis.osti.gov

\section{Disclaimer}

This report was prepared as an account of work sponsored by an agency of the United States Government. Neither the United States Government nor any agency thereof, nor UChicago Argonne, LLC, nor any of their employees or officers, makes any warranty, express or implied, or assumes any legal liability or responsibility for the accuracy, completeness, or usefulness of any information, apparatus, product, or process disclosed, or represents that its use would not infringe privately owned rights. Reference herein to any specific commercial product, process, or service by trade name, trademark, manufacturer, or otherwise, does not necessarily constitute or imply its endorsement, recommendation, or favoring by the United States Government or any agency thereof. The views and opinions of document authors expressed herein do not necessarily state or reflect those of the United States Government or any agency thereof, Argonne National Laboratory, or UChicago Argonne, LLC. 


\title{
Report on Sodium Compatibility of Advanced Structural Materials
}

\author{
Meimei Li, K. Natesan, Y. Momozaki, D. L. Rink, W. K. Soppet, and J. T. Listwan
}

Nuclear Engineering Division

Argonne National Laboratory

September 2011 



\section{ABSTRACT}

This report provides an update on the evaluation of sodium compatibility of advanced structural materials. The report is a deliverable (level 3) in FY11 (M3A11AN04030403), under the Work Package A-11AN040304, "Sodium Compatibility of Advanced Structural Materials" performed by Argonne National Laboratory (ANL), as part of Advanced Structural Materials Program for the Advanced Reactor Concepts. This work package supports the advanced structural materials development by providing corrosion and tensile data from the standpoint of sodium compatibility of advanced structural alloys.

The scope of work involves exposure of advanced structural alloys such as G92, mod.9Cr-1Mo (G91) ferritic-martensitic steels and HT-UPS austenitic stainless steels to a flowing sodium environment with controlled impurity concentrations. The exposed specimens are analyzed for their corrosion performance, microstructural changes, and tensile behavior.

Previous reports examined the thermodynamic and kinetic factors involved in the purity of liquid sodium coolant for sodium reactor applications as well as the design, fabrication, and construction of a forced convection sodium loop for sodium compatibility studies of advanced materials. This report presents the results on corrosion performance, microstructure, and tensile properties of advanced ferritic-martensitic and austenitic alloys exposed to liquid sodium at $550^{\circ} \mathrm{C}$ for up to $2700 \mathrm{~h}$ and at $650^{\circ} \mathrm{C}$ for up to $5064 \mathrm{~h}$ in the forced convection sodium loop. The oxygen content of sodium was controlled by the coldtrapping method to achieve $\sim 1$ wppm oxygen level. Four alloys were examined, G92 in the normalized and tempered condition (H1 G92), G92 in the cold-rolled condition (H2 G92), G91 in the normalized and tempered condition, and hot-rolled HT-UPS. G91 was included as a reference to compare with advanced alloy, G92. It was found that all four alloys showed weight loss after sodium exposures at 550 and $650^{\circ} \mathrm{C}$. The weight loss of the four alloys was comparable after sodium exposures at $550^{\circ} \mathrm{C}$; the weight loss of ferriticmartensitic steels, G92 and G91 is more significant than that of austenitic stainless steel, HT-UPS after sodium exposures at $650^{\circ} \mathrm{C}$. Sodium exposures up to $2700 \mathrm{~h}$ at $550^{\circ} \mathrm{C}$ had no significant influence on tensile properties, while sodium exposures up to $5064 \mathrm{~h}$ at $650^{\circ} \mathrm{C}$ dramatically lowered the tensile strengths of the four alloys. The ultimate tensile strength of H1 G92, H2 G92, and G91 ferritic-martensitic steels was reduced to as much as nearly half of its initial value after sodium exposures at $650^{\circ} \mathrm{C}$. Though the uniform elongation was recovered to some extent, these three ferritic-martensitic steels showed considerable strain softening after sodium exposures. The yield stress of HT-UPS austenitic stainless steel increased, the ultimate tensile strength decreased, and the total elongation was reduced after sodium exposures at $650^{\circ} \mathrm{C}$. The dynamic strain aging effect observed in the as-received HT-UPS specimens became less pronounced after sodium exposures at $650^{\circ} \mathrm{C}$. Microstructural characterization of sodium-exposed specimens showed no appreciable surface deterioration or grain structure changes under an optical microscope, except for the H2 G92 steel, in which the martensite structure transformed to large grain ferrite after sodium exposures at $650^{\circ} \mathrm{C}$. TEM observations of the sodiumexposed H2 G92 steel showed significant recrystallization after sodium exposure for 2700 $\mathrm{h}$ at $550^{\circ} \mathrm{C}$, and transformation of martensite to ferrite and high density of precipitates in 
nearly dislocation-free matrix after sodium exposures at $650^{\circ} \mathrm{C}$. Further microstructural analysis and evaluation of decarburization/carburization behavior is needed to understand the dramatic changes in the tensile strengths of advanced ferritic-martensitic and austenitic steels after sodium exposures at $650^{\circ} \mathrm{C}$. 


\section{TABLE OF CONTENTS}

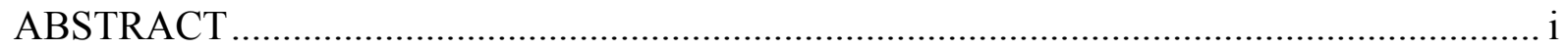

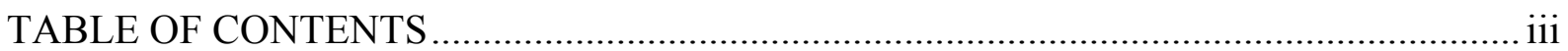

LIST OF TABLES ………………………………..................................................... iv

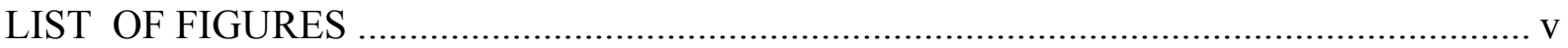

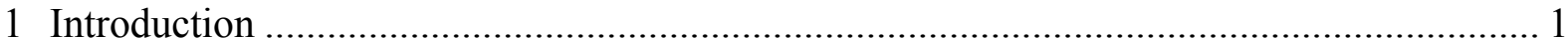

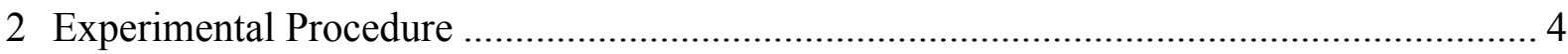

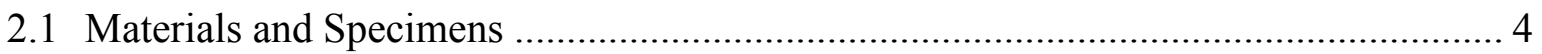

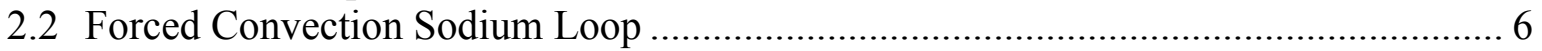

2.3 Sodium Exposure Experiments and Post-Sodium-Exposure Examinations ................... 9

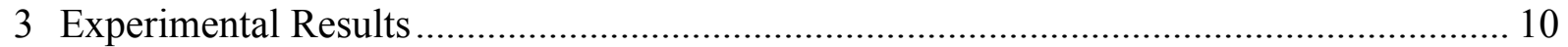

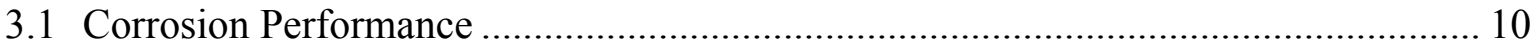

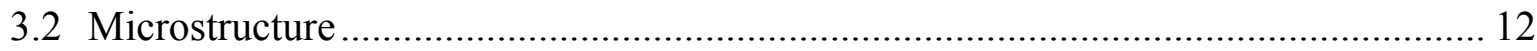

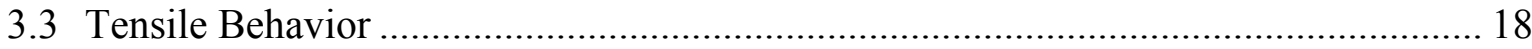

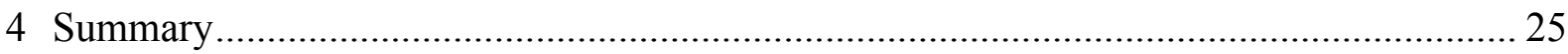

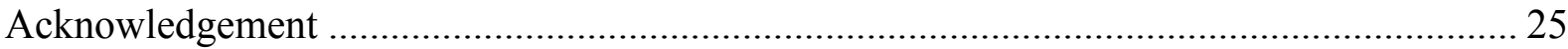

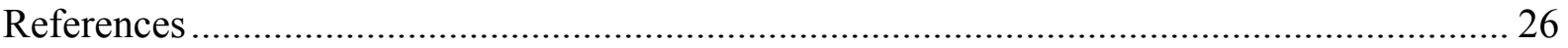




\section{LIST OF TABLES}

Table 2-1. Chemical composition of the selected alloys ...................................................... 5

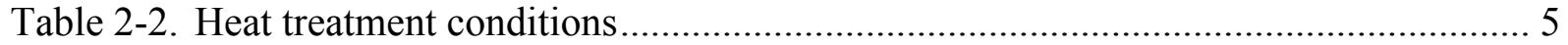

Table 3-1. Effects of sodium exposure on tensile properties............................................. 24 


\section{LIST OF FIGURES}

Figure 1-1. A schematic diagram of sodium-cooled fast reactor............................................

Figure 2-1. Schematic drawing of sheet-type tensile specimens ........................................... 4

Figure 2-2. Schematic diagram of the forced convection sodium loop ....................................

Figure 2-3. Isometric view of the forced convection sodium loop ......................................... 8

Figure 2-4. Forced convection sodium loop for materials testing ........................................... 8

Figure 2-5. Assembly of sodium-exposed specimens .......................................................

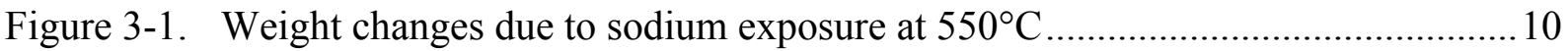

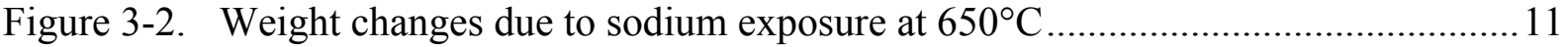

Figure 3-3. Specimen surface appearance after sodium exposure at (a) $550^{\circ} \mathrm{C}$ for

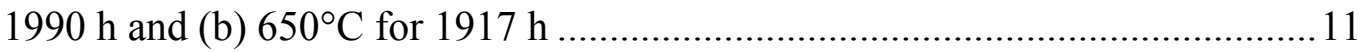

Figure 3-4. SEM micrographs of cross-sections of specimens exposed to sodium for $2700 \mathrm{~h}$ at $550^{\circ} \mathrm{C}$.

Figure 3-5. SEM micrographs of cross-sections of specimens exposed to sodium for $3696 \mathrm{~h}$ at $650^{\circ} \mathrm{C}$.

Figure 3-6. Optical micrographs showing the microstructure of H1 G92 steel (a) in the as-received condition and (b) after sodium exposure at $650^{\circ} \mathrm{C}$ for $3696 \mathrm{~h}$

Figure 3-7. Optical micrographs showing the microstructure of $\mathrm{H} 2 \mathrm{G} 92$ steel (a) in the as-received condition, (b) after sodium exposure for $3696 \mathrm{~h}$ at $650^{\circ} \mathrm{C}$

Figure 3-8. Optical micrographs showing the microstructure of G91 steel (a) in the as-received condition and (b) sodium exposure for $3696 \mathrm{~h}$ at $650^{\circ} \mathrm{C}$

Figure 3-9. Optical micrographs showing the microstructure of HR HT-UPS (a) in the as-received condition and (b) after sodium exposure for $3696 \mathrm{~h}$ at $650^{\circ} \mathrm{C}$

Figure 3-10. TEM images showing microstructures of H2 G92 steel (a) in as-received cold-rolled condition, (b) after exposure to sodium at $550^{\circ} \mathrm{C}$ for $2700 \mathrm{~h}$, and (c) after exposure to sodium at $650^{\circ} \mathrm{C}$ for $3696 \mathrm{~h}$

Figure 3-11. Stress-strain curves of H1 G92 in the as-received condition and after sodium exposure at $550^{\circ} \mathrm{C}$

Figure 3-12. Stress-strain curves of $\mathrm{H1}$ G92 in the as-received condition and after sodium exposure at $650^{\circ} \mathrm{C}$

Figure 3-13. Stress-strain curves of H2 G92 in the as-received cold-rolled condition and after sodium exposure at $550^{\circ} \mathrm{C}$

Figure 3-14. Stress-strain curves of $\mathrm{H} 2 \mathrm{G} 92$ in the as-received cold-rolled condition and after sodium exposure at $650^{\circ} \mathrm{C}$ 
Figure 3-15. Stress-strain curves of G91 in the as-received condition and after sodium exposure at $550^{\circ} \mathrm{C}$......

Figure 3-16. Stress-strain curves of G91 in the as-received condition and after sodium exposure at $650^{\circ} \mathrm{C}$

Figure 3-17. Stress-strain curves of HR HT-UPS in the as-received condition and after sodium exposure at $550^{\circ} \mathrm{C}$.

Figure 3-18. Stress-strain curves of HR HT-UPS in the as-received condition and after sodium exposure at $650^{\circ} \mathrm{C}$. 


\section{Introduction}

Advanced materials are a key element to the development of advanced sodium-cooled fast reactors. Advanced structural materials allow compact and simple design of reactor structure, and have the potential to reduce the construction and operational costs for next-generation nuclear reactors. Several advanced alloys have been selected for further development in support of sodium-cooled fast reactors [Busby et al 2008]. R\&D has focused on advanced ferriticmartenstic steels, G92 and G92 with special thermal-mechanical treatment, and advanced austenitic stainless steels, HT-UPS (High-Temperature Ultrafine Precipitate-Strengthened) steel.

The Advanced Reactor Concepts campaign has focused on the sodium-cooled reactor concept because of its technical maturity. The current needs are for larger, more reliable, more economical reactors suitable for commercial nuclear power generation. Research and development focuses on three areas including advanced materials, innovative components and systems, and computer models and simulation. Inherent in this research and development is the selection and adequate long-term performance of reactor components that are directly exposed to the sodium coolant at elevated temperatures.

Figure 1-1 shows a schematic of a sodium-cooled fast reactor. In these reactors, heat is generated from fission reactions in a nuclear-fueled core. The heat is removed by liquid sodium flowing through the core, the heat is transferred to a steam system, and the steam is used to drive a turbine. Because of excellent heat transfer properties, liquid sodium has been selected as the coolant and heat transport medium. In general, austenitic stainless steels are used for the fuel cladding, in-core structural components, piping, and intermediate heat exchanger. Ferritic steels are, at present, used for the steam generator in the secondary coolant system. The selection of a particular material and combinations thereof that will be used in both primary and secondary circuits is based upon a number of factors. For in-core applications, the stability of the material in the fast-neutron environment and compatibility with the sodium coolant and the fuel (including possible fission-product interactions) are of primary concern. In the case of the steam generator, the resistance of the material to aqueous chloride and caustic cracking as well as minimization of corrosion wastage rates due to sodium-water reaction products in the event of a tube failure have important bearing on the material selection.

In general, structural materials can undergo a variety of interactions upon exposure to liquid sodium. The extent of interaction depends upon the conditions of temperature, temperature gradient, sodium velocity and purity, the materials of construction, and external sources and sinks for the impurities. The interactions can be broadly classified into either metallic or nonmetallic element mass transfer. Metallic element mass transfer usually establishes a go/nogo type of evaluation of an alloy for use in sodium environment, based upon material wastage or component section loss. A classic example of this is the unacceptable performance of vanadium base alloys in sodium of normal reactor purity. Upon selection of an alloy for sodium service, corrosion allowances that account for metallic element transfer can be incorporated into the design of specific components. Nonmetallic elements, such as oxygen, carbon, nitrogen, and hydrogen, are known to migrate in structural material/sodium systems (under both isothermal and non-isothermal conditions) as a result of chemical activity differences. 


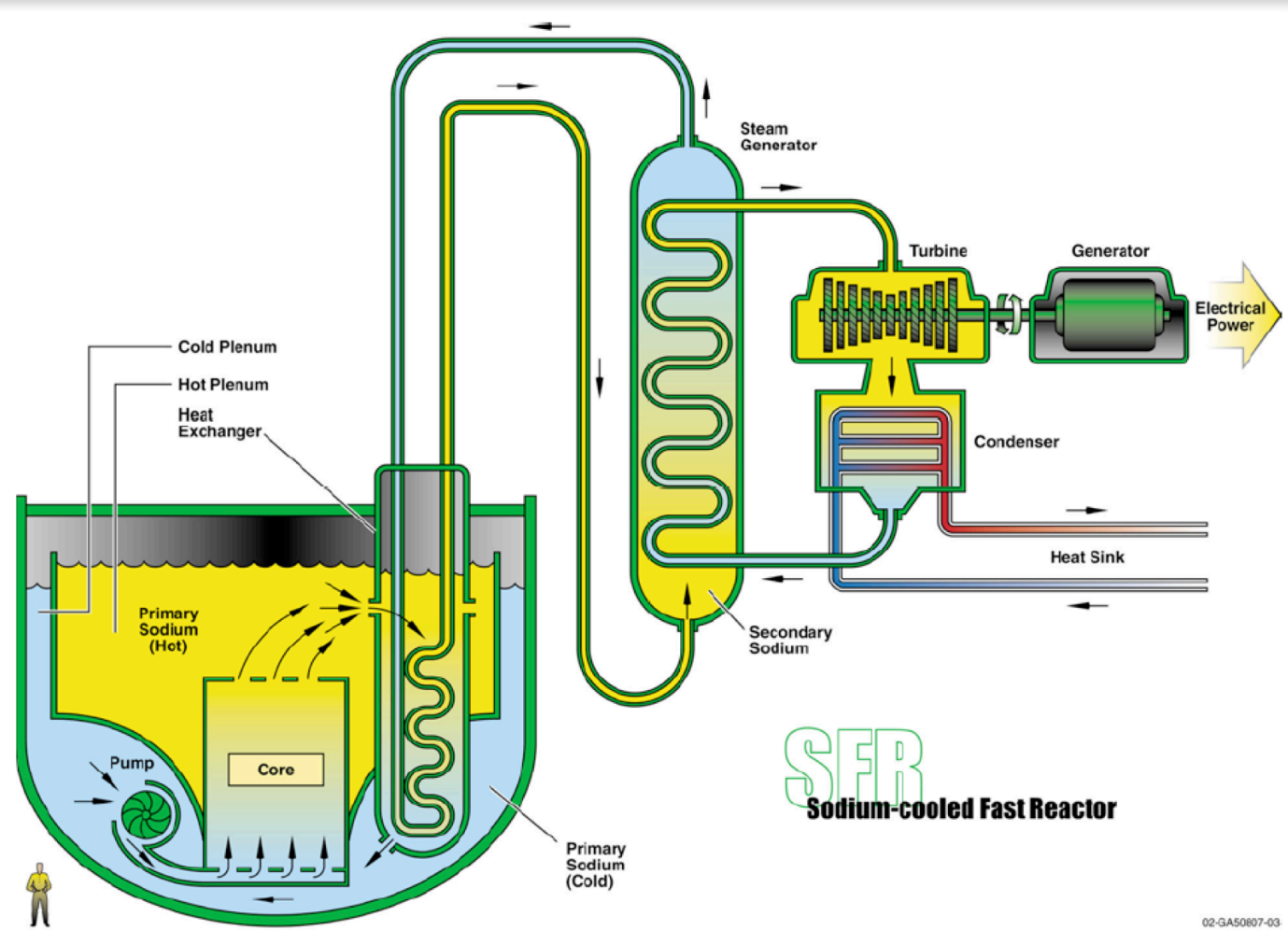

Figure 1-1. A schematic diagram of sodium-cooled fast reactor.

A solid metal dissolves in a liquid metal by the diffusion of atoms from the lattice of the solid metal into a boundary layer, followed by transfer of the dissolved atoms from the boundary layer into the bulk liquid. In general, the rate of dissolution depends on the solubility of the solute element in the liquid metal, temperature, and hydrodynamic conditions of the solid/liquid interface. Apart from the atomistic dissolution of metallic elements into sodium, mass transfer can also occur by formation of corrosion products on the metallic surfaces due to interaction between reactants in sodium with the metals to form corrosion products that subsequently erode/spall into the flowing sodium. These corrosion products generally consist of binary or complex oxides of various metals. The dissolution of metallic elements is generally unavoidable especially in systems with temperature gradients, and needs to be minimized to control the metal wastage in regions at elevated temperatures, limit the deposition of corrosion products in the low temperature regions of the system, and also to control the amount of radioactive corrosion product transport in the primary sodium circuit of the fast reactor. The approach to minimize the problem is to select materials that have 1) relatively low solubility in sodium, and 2) solubility values with small temperature dependence. Metallic element mass transfer usually establishes a go/no-go type of evaluation of an alloy for use as a structural material for service in liquid sodium environment.

Nonmetallic elements such as oxygen, carbon, nitrogen, and hydrogen are known to migrate in structural materials/sodium systems as a result of chemical activity differences that occur in isothermal or non-isothermal systems. Transfer of these elements also occurs in systems where combinations of materials of different composition are used. By examining the partitioning of nonmetallic elements between the structural alloy and sodium, the extent to which oxygen, 
carbon, and nitrogen interact in the structural material-sodium systems can be assessed. From the operation of the sodium-fast-reactor standpoint, the oxygen impurity in sodium can be controlled to $\approx 1 \mathrm{ppm}$ which would result in acceptable corrosion of austenitic and ferritic steels and nickel-base alloys at a typical maximum operating temperature of $600^{\circ} \mathrm{C}$ for the coolant. The solubility of nitrogen in sodium is low in the reactor anticipated operating temperatures and its effect on the materials performance may not be significant. On the other hand, observations by various investigators, that materials of nominally the same composition with different degrees of decarburization/carburization in sodium loops operating over similar temperature ranges, have resulted in questions regarding the extrapolation of results obtained in small scale sodium loops to large reactor systems. Since carbon concentration in a given system is established by a dynamic equilibrium between the carbon sources and carbon sinks present in the system, it could vary from system to system as well as over time within a system. It is necessary to evaluate the influence of carbon in sodium on the microstructural and mechanical properties of advanced structural materials.

In previous reports [Natesan et al. 2009, 2010], we addressed the thermodynamics and kinetics of metallic and nonmetallic impurity elements in sodium and their role in the corrosion of structural materials such as austenitic stainless steels and ferritic steels. The reports also presented the available data for the impurity elements, experience on control and maintenance of the impurities in sodium systems, and the impact of various impurity elements, especially nonmetallic elements, on the corrosion performance of various structural components in sodiumcooled reactors. A forced convection sodium loop was constructed at Argonne National Laboratory for sodium compatibility studies of advanced materials. This report presents the first time the results of corrosion behavior, microstructural changes and tensile properties of sodiumexposed specimens of G92 and G91 ferritic-martensitic steels and HT-UPS austenitic steel. 


\section{Experimental Procedure}

\subsection{Materials and Specimens}

Four alloys were investigated, including normalized and tempered G92 ferritic-martensitic steel (referred to H1 G92), cold-rolled G92 ferritic-martensitic steel (referred to H2 G92), normalized and tempered ferritic-martensitic steel G91, and hot-rolled austenitic stainless steel, HT-UPS (referred to HR HT-UPS). G91 steel was included as a reference to compare with G92. All four materials were provided by Oak Ridge National Laboratory (ORNL). The chemical analysis for G91 and H1 G92 was carried out by Bodycote Materials Testing. The chemical compositions of H2 G92 and HR HT-UPS were provided by ORNL. The chemical compositions of these alloys are given in Table 2-1.

Heat 1 of G92 was in 1 in.-thick plate form, normalized at $1050^{\circ} \mathrm{C}$ and tempered at $750^{\circ} \mathrm{C}$ for $2 \mathrm{~h}$ and air cooled. Heat 2 of G92 was 0.030 in. thick sheet. The processing of H2 G92 involved hot rolling of a 0.325 in. thick plate to 0.110 in. thick sheet, air cooling, a subsequent heat treatment at $1080^{\circ} \mathrm{C}$ for $0.5 \mathrm{~h}$ and tempering at $750^{\circ} \mathrm{C}$ for $2 \mathrm{~h}$, air cooling, and a final cold-rolling to a 0.030 in. thick sheet. G91 steel was in the plate form with a thickness of 0.375 in.. It was normalized at $1050^{\circ} \mathrm{C}$ and tempered at $760^{\circ} \mathrm{C}$ for $1 \mathrm{~h}$ and air cooled. HR HT-UPS was in plate form with a thickness of $0.75 \mathrm{in}$. The final process was hot rolling at $1200^{\circ} \mathrm{C}$ followed by air cooling. The heat treatment conditions are summarized in Table 2-2.

Sheet-type tensile specimens with an extended grip section were used for sodium exposure experiments. The extended grip was designed for microstructural characterization of the same specimen to be used for tensile property measurements. A schematic drawing of the sheet-type tensile specimen is given in Fig. 2-1. The tensile specimens were electrical-discharge-machined with the gage parallel to the rolling direction. The specimens have gage dimensions of $7.62 \times$ $1.52 \times 0.75 \mathrm{~mm}$ with a total length of $35 \mathrm{~mm}$. Specimens were polished to remove any surface oxide films before sodium exposure. Prior to sodium exposure, each specimen was weighed three times using OHAUS Model AP250 analytical balance to a precision of $10 \mu \mathrm{g}$; the thickness of each specimen was measured three times using a micrometer to a precision of 0.0001 in.

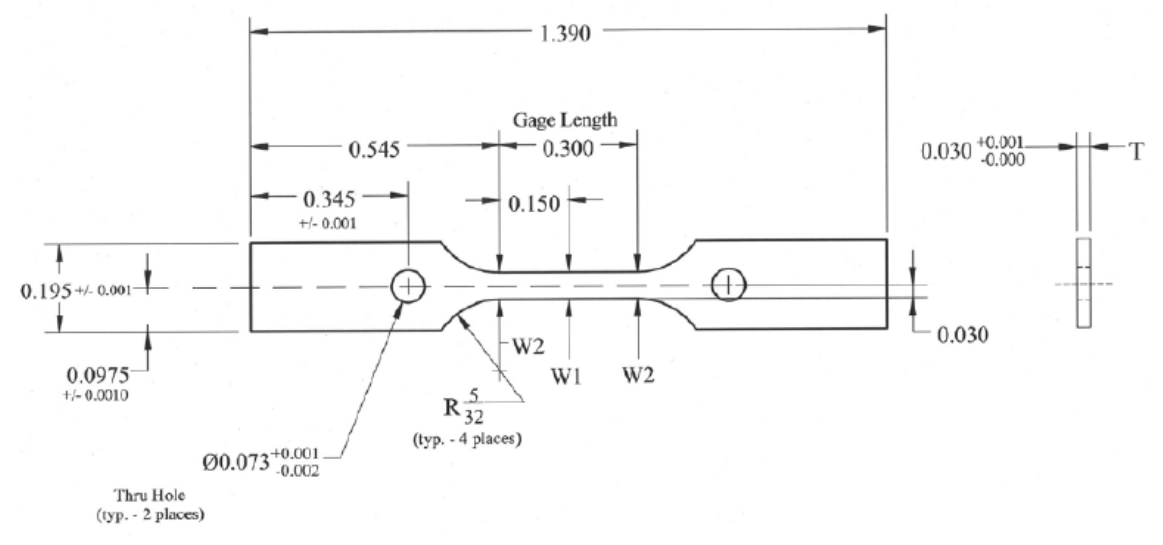

Figure 2-1. Schematic drawing of sheet-type tensile specimens (unit: inch). 
Table 2-1. Chemical composition (in wt $\%$ ) of the selected alloys

\begin{tabular}{lcccccccccccccccc}
\hline \multicolumn{1}{c}{ Alloy } & $\mathrm{Fe}$ & $\mathrm{C}$ & $\mathrm{Mn}$ & $\mathrm{P}$ & $\mathrm{S}$ & $\mathrm{Si}$ & $\mathrm{Ni}$ & $\mathrm{Cr}$ & $\mathrm{Mo}$ & $\mathrm{B}$ & $\mathrm{Ti}$ & $\mathrm{Nb}$ & $\mathrm{V}$ & $\mathrm{N}$ & $\mathrm{W}$ \\
\hline HR HT-UPS & Bal & 0.058 & 2.08 & 0.048 & $6 \mathrm{ppm}$ & 0.28 & 16.06 & 14.54 & 2.33 & 0.007 & 0.15 & 0.15 & 0.53 & 0.028 & \\
H1 NF616 & Bal & 0.11 & 0.46 & 0.009 & $<0.005$ & 0.03 & 0.06 & 9.09 & 0.43 & 0.0009 & - & 0.08 & 0.20 & 0.057 & 1.84 \\
H2 NF616 & Bal & 0.092 & 0.45 & 0.007 & 0.011 & 0.15 & 0.21 & 9.02 & 0.45 & 0.0023 & & 0.07 & 0.03 & 1.71 \\
G91 & bal & 0.09 & 0.46 & 0.012 & $<0.005$ & 0.41 & 0.11 & 8.33 & 1.04 & 0.05 & - & 0.05 & 0.22 & 0.059 & - \\
\hline
\end{tabular}

Table 2-2. Heat treatment conditions

\begin{tabular}{lr}
\hline Alloy & Heat treatment \\
\hline HR HT-UPS & Hot-rolled at $1200^{\circ} \mathrm{C}$ \\
H1 NF616 & Normalized at $\sim 1050^{\circ} \mathrm{C}$, tempered at $750^{\circ} \mathrm{C}$ for $2 \mathrm{~h}$, and air cooled \\
H2 NF616 & Normalized at $1080^{\circ} \mathrm{C}$ for $0.5 \mathrm{~h}$, tempered at $750^{\circ} \mathrm{C}$ for $2 \mathrm{~h}$, air cooled, and cold- \\
rolled
\end{tabular}




\subsection{Forced Convection Sodium Loop}

A forced convection sodium loop was constructed at Argonne National Laboratory for testing the advanced structural materials. The design features of sodium loop are shown in a schematic in Fig. 2-2, and in an isometric view in Fig. 2-3, respectively. Figure 2-4 shows a photo of the completed loop. The loop consists of a specimen-exposure vessel with a heat exchanger, one electromagnetic pump, two electromagnetic flow meters, economizer, and a cold trap. Each component is connected by $1 / 2$-in. stainless steel tubing. Sodium flows from the specimenexposure vessel with a drop in its temperature as it flows through the economizer 1 . The electromagnetic pump, EP021 pushes sodium and some goes through the electromagnetic flow meter, FM141. This sodium flows back to the vessel through the economizer 1. Remaining sodium flows through the electromagnetic flow meter, FM 241 and the economizer 2 while further reducing the temperature. The sodium then flows into the cold trap, in which the sodium purity is maintained. The clean sodium flows back through the economizer 2 and warms up. Finally, the clean sodium with further increase in its temperature in the economizer 1 flows back into the vessel. The loop is placed over a stainless steel drip pan for spill control, and placed in a small containment made from sheet metal for smoke control in case of sodium leak. The system is designed to circulate sodium with an argon cover gas through the specimen-exposure vessel and the associated loop for an extended period of time without an operator.

The specimen-exposure vessel is constructed from 8 -in., schedule 40, stainless steel pipe. A heat exchanger made of 1-1/4-in., schedule 40, stainless steel pipe is attached to the vessel. The volume of the vessel is approximately 10 liters. The vessel has three penetrations at the top for loading samples as well as small penetrations for a level probe, thermocouple, and Argon/vacuum line. Each of the three penetrations for sample loading has a ball valve and a gate valve. The penetration is vertical and the ball valve is located above the gate valve. The ball valve isolates the inside of the tank from outside atmosphere and the gate valve protects the ball valve from sodium condensation. The Argon/vacuum line is fitted with a pressure gauge. The cold trap and economizer are constructed from 3-in. and 1-1/2-in., schedule 40, stainless steel pipe, respectively. The cold trap is packed with stainless steel mesh, providing a large surface area to facilitate precipitation of impurities. The cold trap is equipped with its own heaters, air blower, and Type-K thermocouples for precise temperature control, particularly at low temperatures in the range of $100-150^{\circ} \mathrm{C}$. The electromagnetic pump is a conventional, direct current, conduction electromagnetic pump with a yoke consisting of two permanent samariumcobalt (SmCo) magnets. The pump is powered by a direct current power supply (Hewlett Packard, HP 6681 A) that can deliver up to 580 A of direct current. The electromagnetic flow meters are also simple direct current electromagnetic devices with a yoke consisting of two SmCo magnets.

The loop is heated by a number of ceramic band heaters attached to the loop components. Also several heating wires are used to heat the tubing. A number of Type $\mathrm{K}$ thermocouples whose precision is within $2.2^{\circ} \mathrm{C}$ at $\leq 293.3^{\circ} \mathrm{C}$ or $0.75 \%$ at higher temperatures are attached to the loop at various locations to monitor temperatures, and some of them are used to control the heaters. The heaters are grouped into 8 different zones to regulate heating of each zone as well as for power distribution. Each heating zone is controlled by a solid-state relay based control system. For redundancy and to ensure the safe operation of the loop, each control system is 
equipped with two independent temperature controllers and each controller has its own thermocouple for temperature monitoring. One controller is to accurately control the temperature around the set point using the solid-state relay and another controller acts as a circuit breaker using an electro-mechanical relay to turn off the power to the zone when the reading from the thermocouple exceeds the over-temperature set point. This latter heater controller is to provide an extra over-temperature protection to the heater control system. Eight thermocouple bundles, each corresponding to different zones, are employed. The temperatures of the various parts of the system are monitored by Type $\mathrm{K}$ thermocouples. All the tips of these thermocouples attached to the outside wall of the loop were mounted using high temperature, high thermal conductive adhesive to ensure good thermal contact. Two thermocouples are embedded in the cold trap. A thermocouple is also inserted in the sample vessel to better monitor the sodium temperature and to achieve/maintain the desired temperatures for long-term exposure of specimens.. The thermocouples monitoring various loop temperatures are connected to a data acquisition system, and collected data are sent to the computer for display and storage.

The total amount of sodium in the loop is approximately $10 \mathrm{~kg}$. Maximum operating pressure and temperature are rated at $5 \mathrm{psig}$ and $700^{\circ} \mathrm{C}\left(1292^{\circ} \mathrm{F}\right)$ for the sample vessel and 5 psig and $450^{\circ} \mathrm{C}$ for the tubing part of the loop, except the economizer and the cold trap where the maximum temperature is $300^{\circ} \mathrm{C}$. Three specimen stages are available for loading corrosion coupon or sheet-type tensile specimens for sodium compatibility tests.

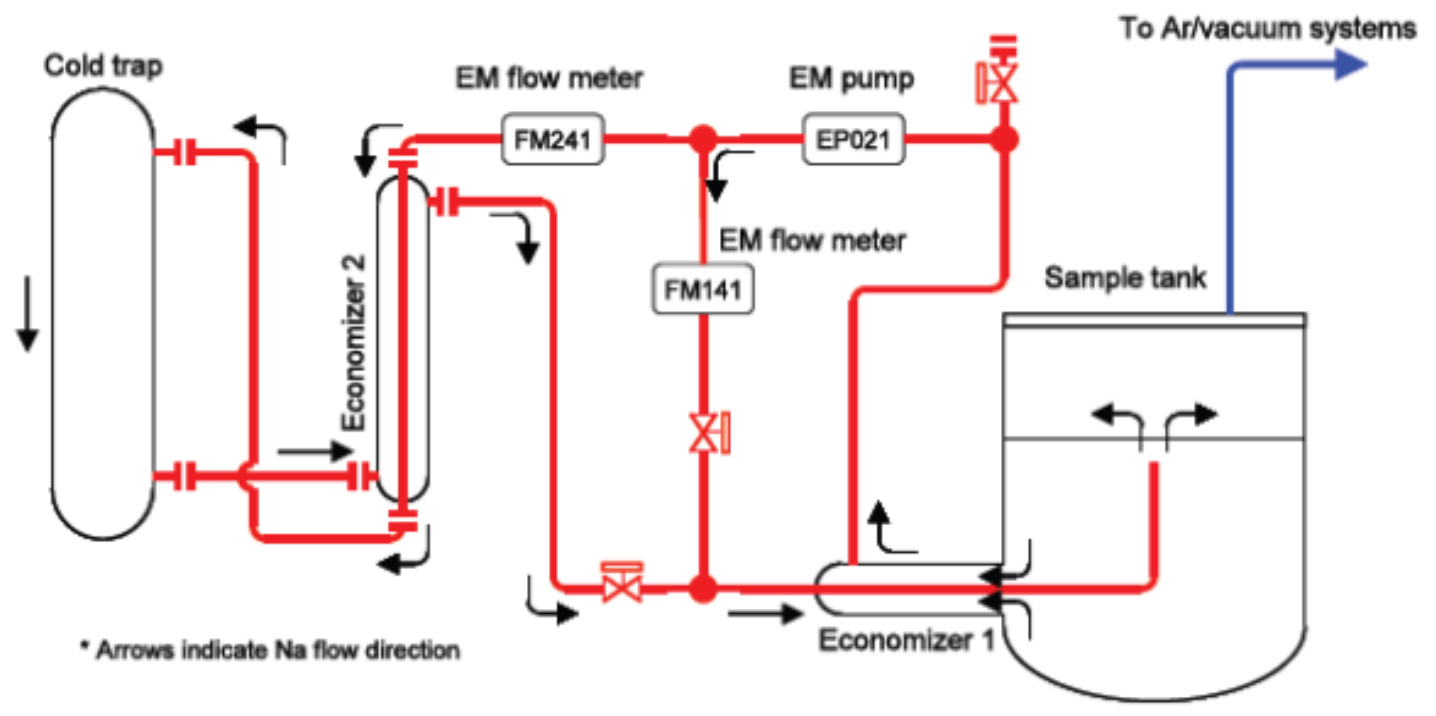

Figure 2-2. Schematic diagram of the forced convection sodium loop. 


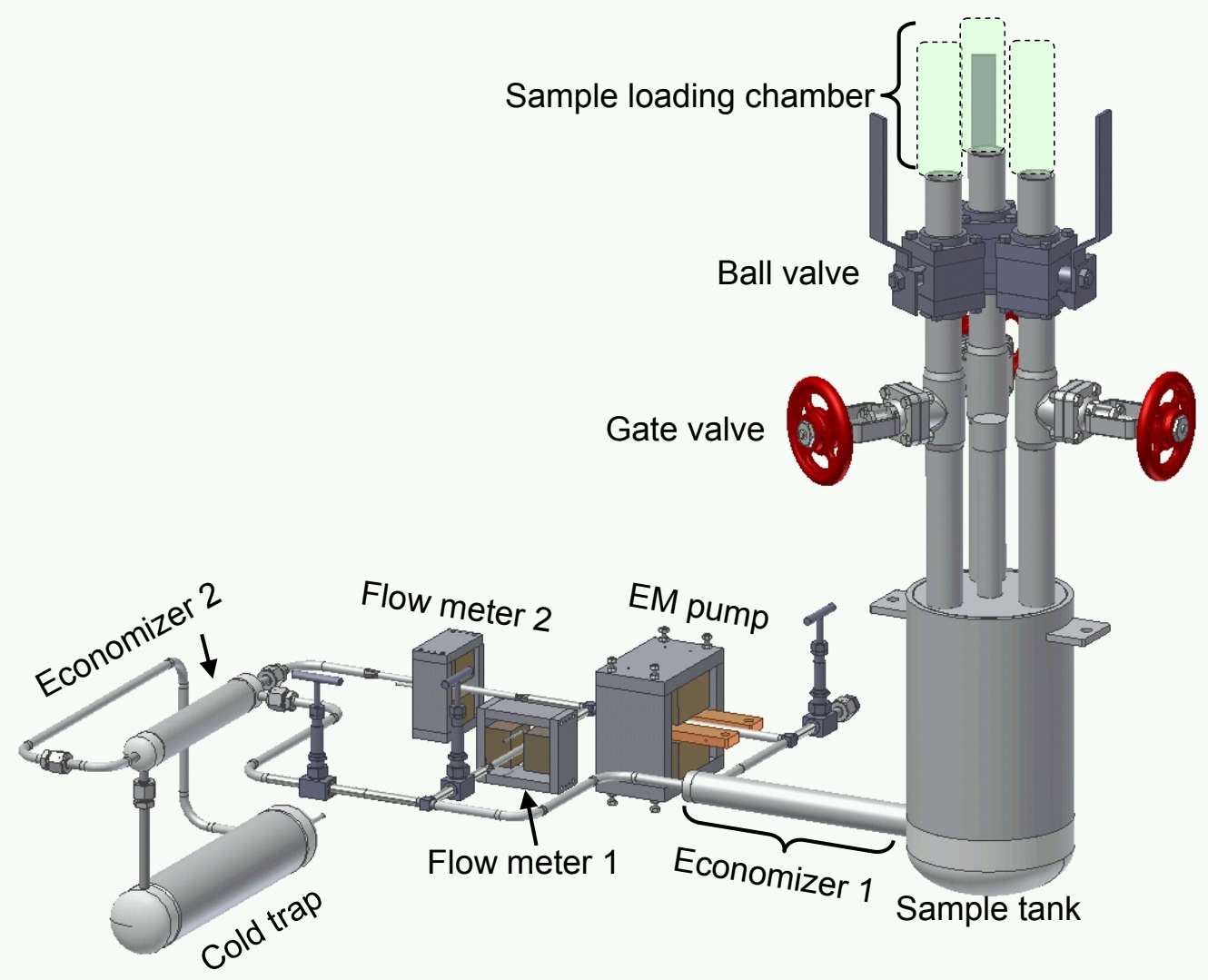

Figure 2-3. Isometric view of the forced convection sodium loop.

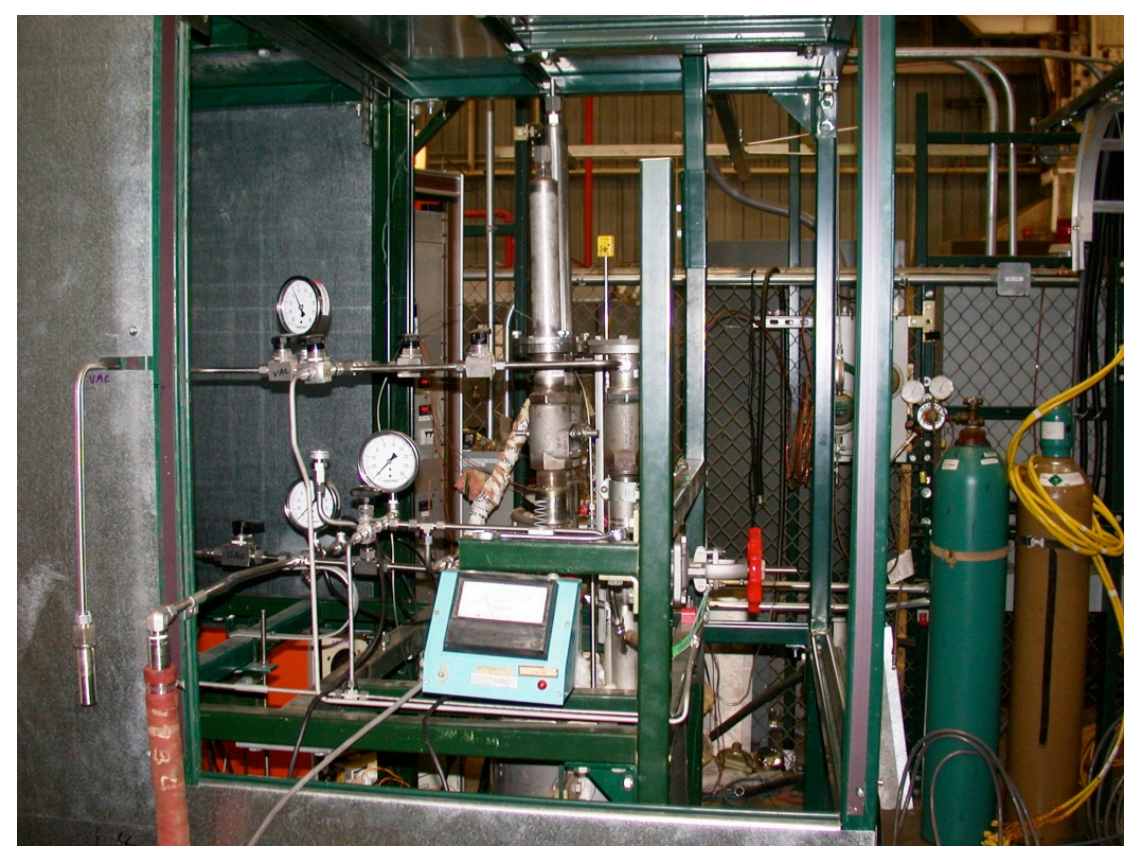

Figure 2-4. Forced convection sodium loop for materials testing. 


\subsection{Sodium Exposure Experiments and Post-sodium-exposure Examinations}

Sodium exposure experiments were performed at temperatures of $550^{\circ} \mathrm{C}$ for up to $2700 \mathrm{~h}$ and at $650^{\circ} \mathrm{C}$ for up to $5064 \mathrm{~h}$. Sheet-type tensile specimens were assembled in a specimen holder, as shown in Fig. 2-5 and loaded into the sodium loop. The oxygen content of sodium was controlled by the cold trap. The temperature of the cold trap was maintained at $\sim 125^{\circ} \mathrm{C}$ to ensure that the oxygen concentration was at $\sim 1$ wppm during specimen exposure.

After an extended exposure period, the sample holder was removed from the loop for postsodium-exposure examination. The specimens were cleaned with alcohol. Final cleaning was done with water to remove any sodium residues. Specimen surfaces were visually inspected and recorded by a digital camera. Mass and thickness measurements were conducted to determine the mass and thickness changes. The extended grip sections of the exposed tensile specimen were cut from both ends for the use of microstructural characterization. Metallographic specimens were made from the cross section for examination of the specimen surfaces and microstructure by optical microscopy $(\mathrm{OM})$ and scanning electron microscopy (TEM). The polished specimens of G92 and G91 steels were chemically etched with an etchant of $5 \mathrm{ml}$ $\mathrm{HNO}_{3}, 1 \mathrm{ml} \mathrm{HF}$ and $50 \mathrm{ml} \mathrm{H}$ O. The HT-UPS specimens were etched with an etchant of $10 \mathrm{ml}$ $\mathrm{HNO}_{3}, 30 \mathrm{ml} \mathrm{HCl}$ and $30 \mathrm{ml} \mathrm{H} \mathrm{H}_{2} \mathrm{O}$. Thin foil specimens of 3-mm in diameter were made for microstructural characterization by transmission electron microscopy (TEM). Specimens were electropolished to perforation using a Tenupol twin-jet polishing unit. The electropolishing solution was $95 \%$ methanol and $5 \%$ perchloric acid cooled to about $\sim-40^{\circ} \mathrm{C}$. Microstructure was examined in the Hitachi 9000 NAR microscope operated at $200 \mathrm{kV}$.

Sodium-exposed specimens were tested under uniaxial tension to examine the effects of sodium exposure on tensile properties. Tensile tests were performed on a MTS screw-driven machine in air at a strain rate, $0.001 \mathrm{~s}^{-1}$ at the same temperature as the specimen exposure temperature. The tensile specimens were heated in a three-zone air furnace. The applied load was recorded by a load cell and the specimen displacement was recorded using a linear variable differential transformer (LVDT) attached to the load train. The engineering tensile properties were determined from an analysis of data files on the load vs. displacement.

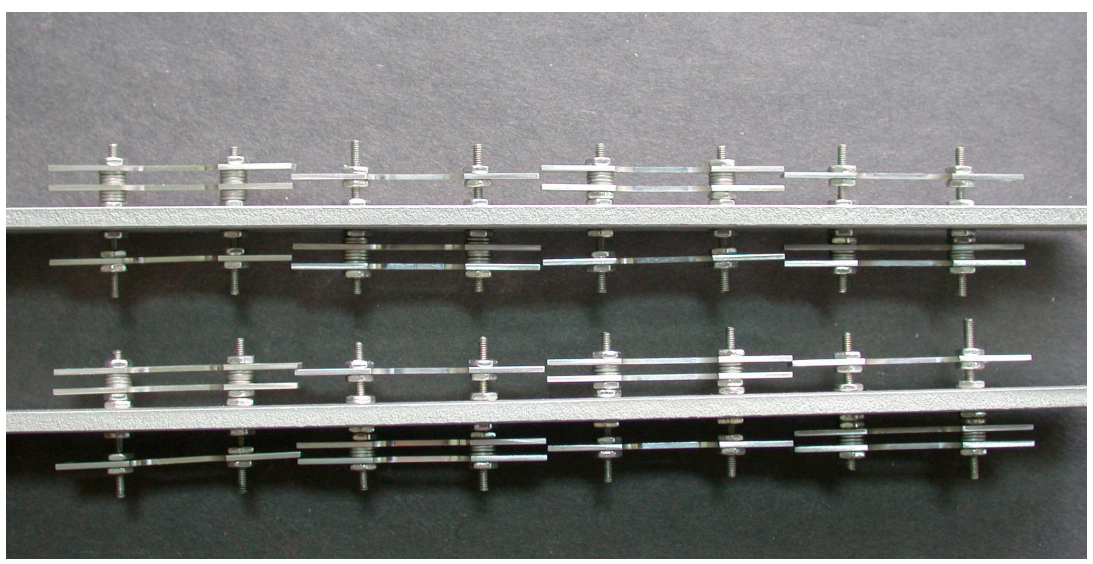

Figure 2-5. Assembly of sodium-exposed specimens. 


\section{Experimental Results}

\subsection{Corrosion Performance}

Weight changes due to sodium exposure are shown in Figs. 3-1 and 3-2 for specimens exposed to sodium at 550 and $650^{\circ} \mathrm{C}$, respectively. The data represent an average of three measurements for a single specimen. All four alloys showed weight loss at the exposure temperatures of 550 and $650^{\circ} \mathrm{C}$. At $550^{\circ} \mathrm{C}$, the weight loss of the four alloys continued with increasing exposure time. No obvious saturation of the weight loss was observed up to $2700 \mathrm{~h}$. The weight losses of the four alloys are comparable for a given exposure time at $550^{\circ} \mathrm{C}$.

At the exposure temperature of $650^{\circ} \mathrm{C}$, the weight loss of ferritic-martensitic steels, G92 and G91 are much more significant than that of HR HT-UPS steel. On average, the weight loss of ferritic-martensitic steels is three times higher than that in HT-UPS steel. Among the three ferritic-martensitic steels, the normalized and tempered G92 steel showed marginally smaller weight loss than the cold-rolled G92 steel and the normalized and tempered G91 steel. The weight loss of all four alloys showed an apparent saturation beyond the $1000 \mathrm{~h}$ exposure time at $650^{\circ} \mathrm{C}$.

No measurable thickness changes were observed under any of the sodium-exposure conditions examined thus far. Figure 3-3 shows the specimen surface appearance after sodium exposure for $1990 \mathrm{~h}$ at $550^{\circ} \mathrm{C}$ [Fig. 3-3(a)] and for $1917 \mathrm{~h}$ at $650^{\circ} \mathrm{C}$ [Fig. 3-3(b)], respectively. Under both sodium exposure conditions, specimens lost surface finish, but the surface remained smooth, and no spalling and surface deterioration was visually observable.

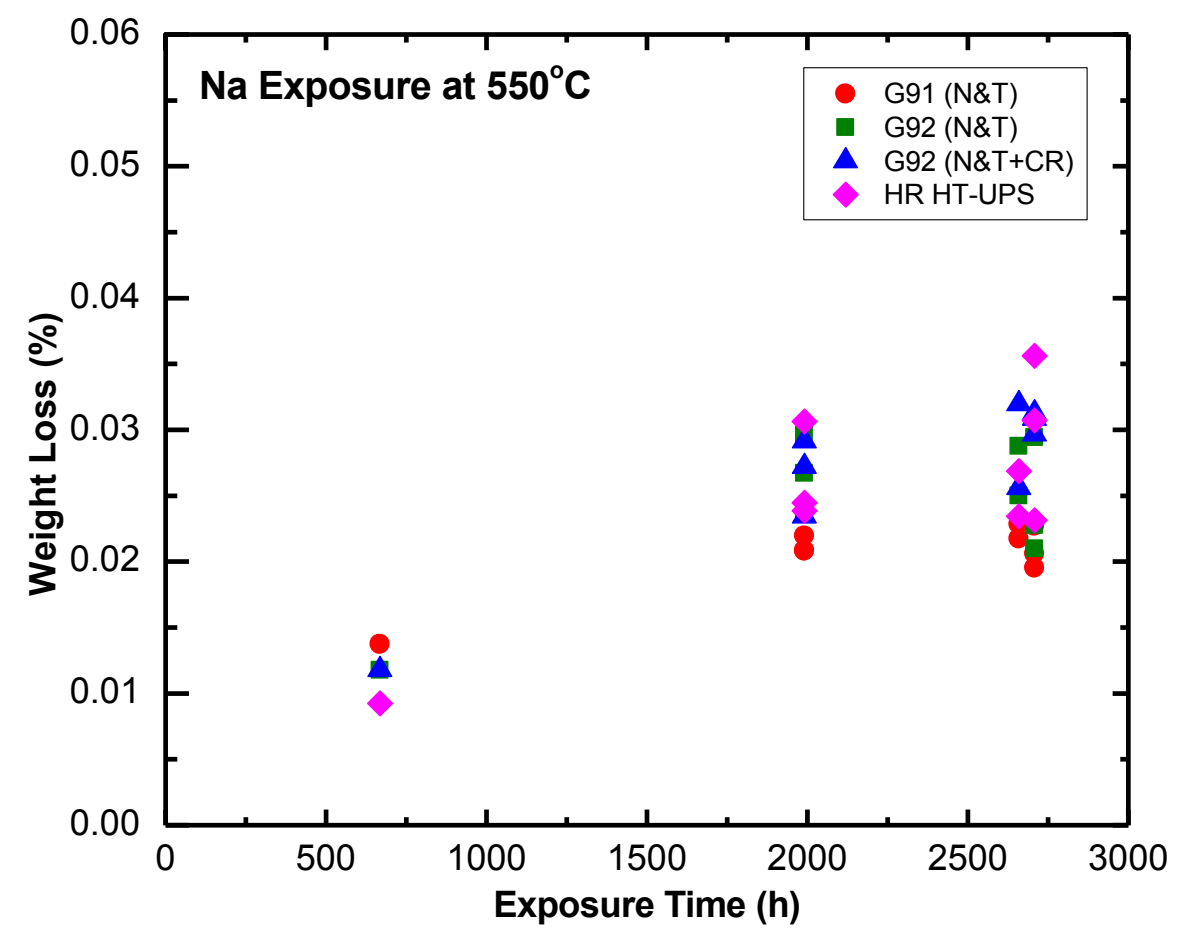

Figure 3-1. Weight changes due to sodium exposure at $550^{\circ} \mathrm{C}$. 


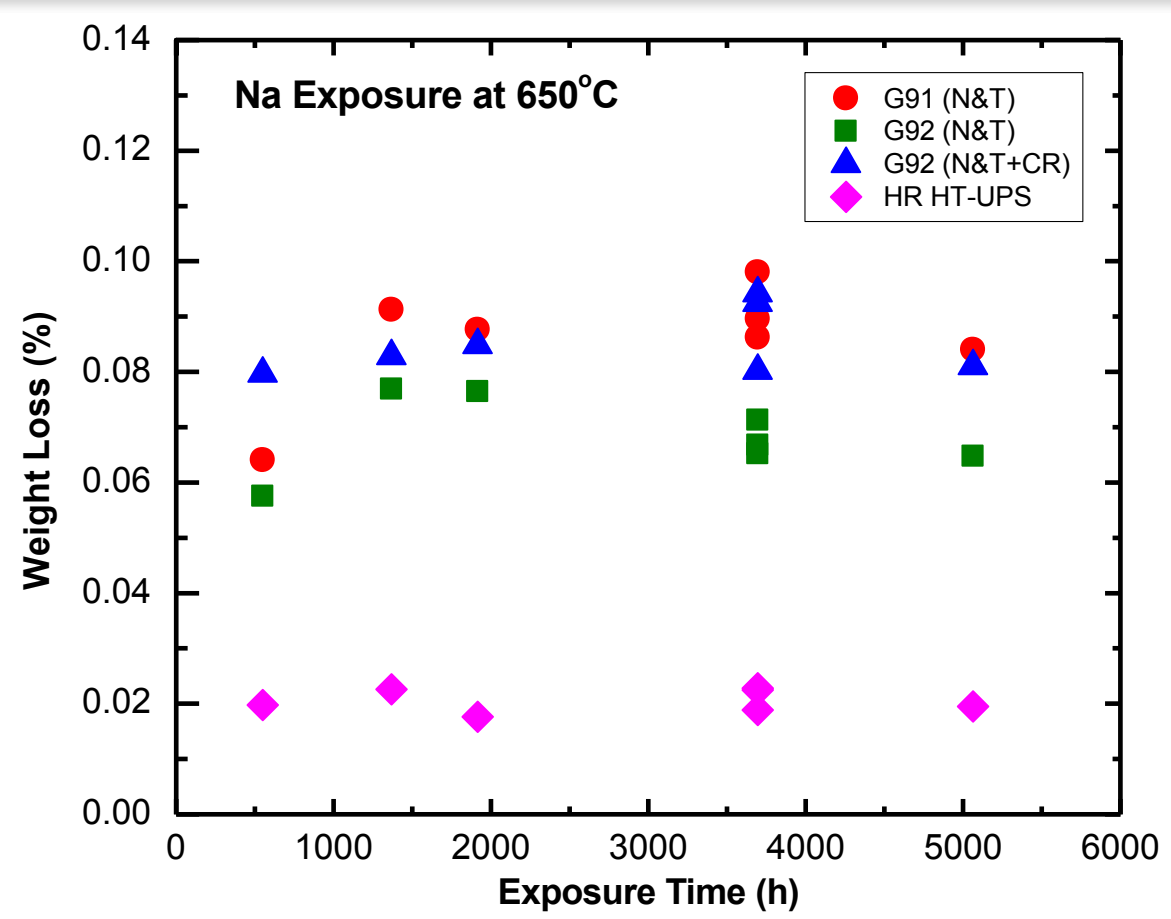

Figure 3-2. Weight changes due to sodium exposure at $650^{\circ} \mathrm{C}$.

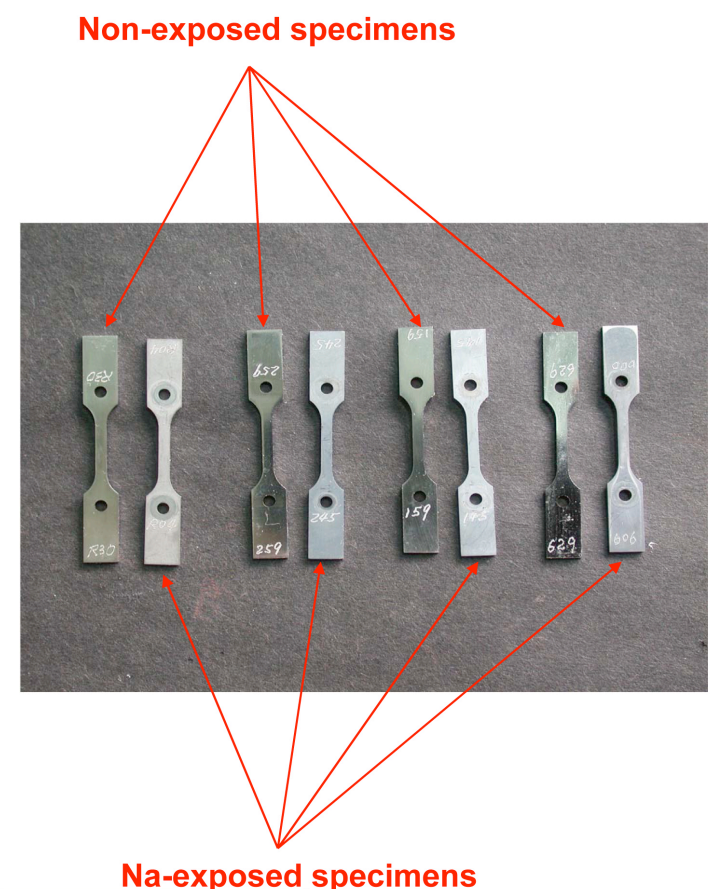

Na-exposed specimens

(a) Sodium exposure at $550^{\circ} \mathrm{C}$ for $1990 \mathrm{~h}$

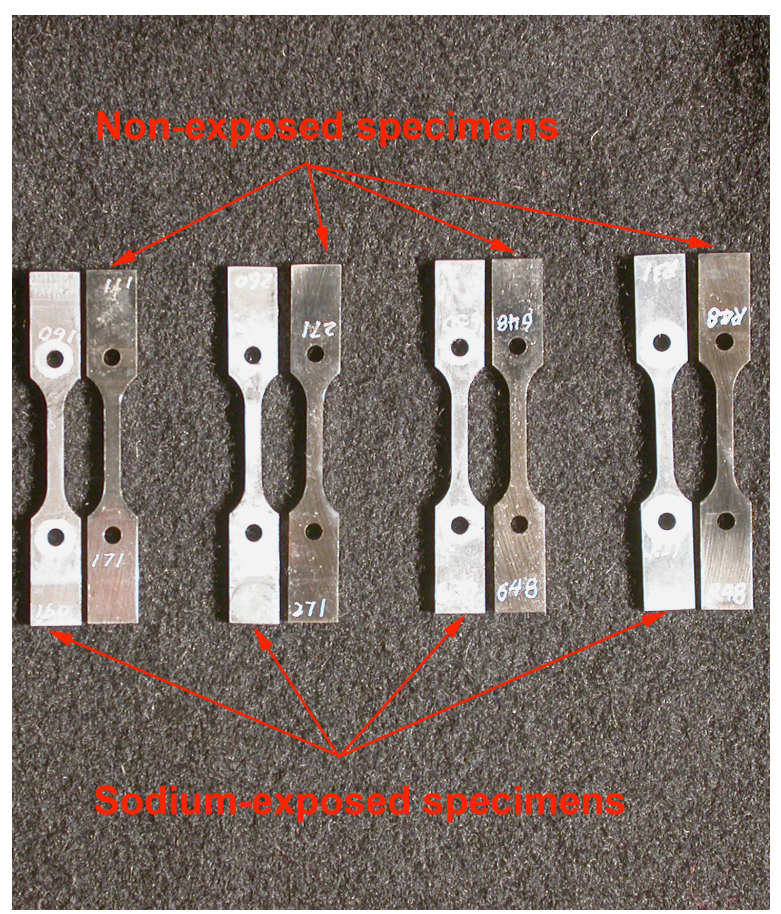

(b) Sodium exposure at $650^{\circ} \mathrm{C}$ for $1917 \mathrm{~h}$

Figure. 3-3. Specimen surface appearance after sodium exposure at (a) $550^{\circ} \mathrm{C}$ for $1990 \mathrm{~h}$ and (b) $650^{\circ} \mathrm{C}$ for $1917 \mathrm{~h}$. 
Cross-sectional specimens were made from the sodium-exposed specimens and examined by SEM. Figures 3-4 and 3-5 shows SEM micrographs of the specimens exposed to sodium for $2700 \mathrm{~h}$ at $550^{\circ} \mathrm{C}$, and for $3696 \mathrm{~h}$ at $650^{\circ} \mathrm{C}$. No evident formation of a corrosion layer was observed in H1 G92 and H2 G92 ferritic steels and HR HT-UPS austenitic steel. Slight surface deterioration was observed in G91 steel. Note that the dramatic structural change in $\mathrm{H} 2 \mathrm{G} 92$ after sodium exposure at $650^{\circ} \mathrm{C}$.

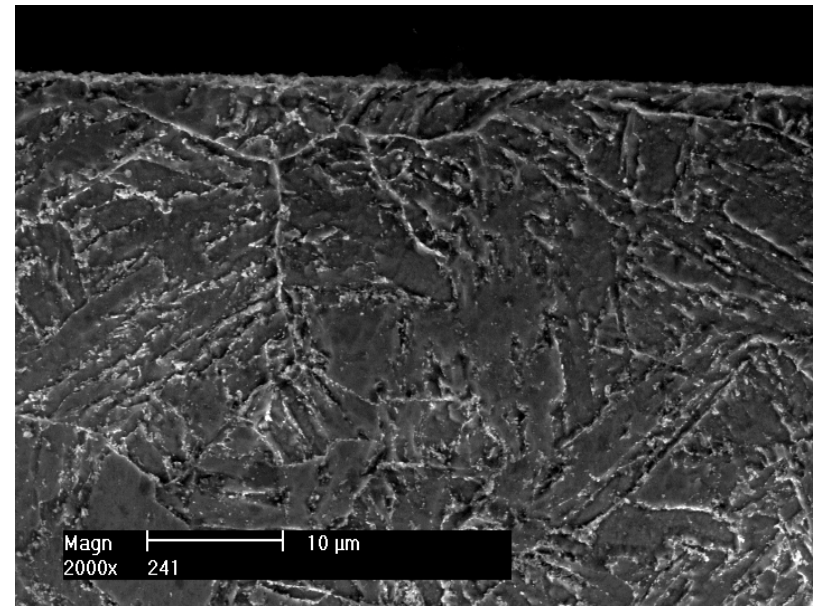

(a) H1 G92

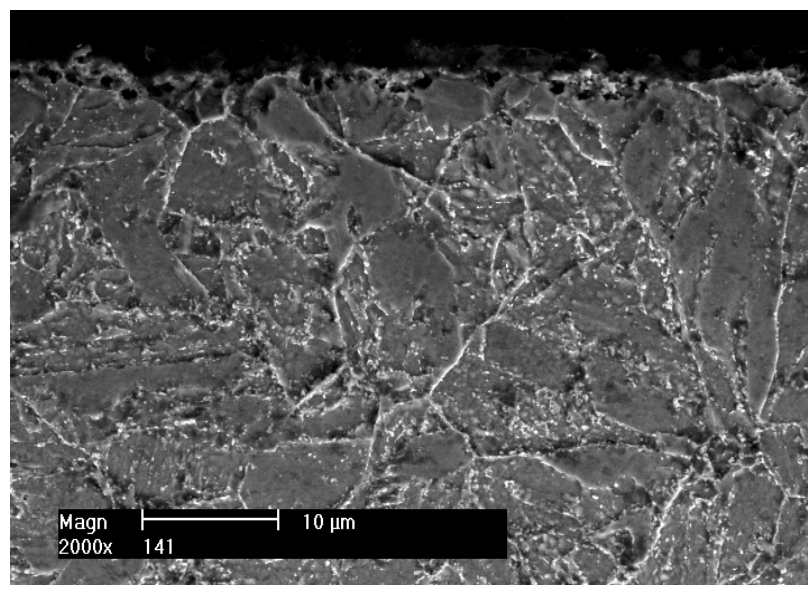

(c) G91

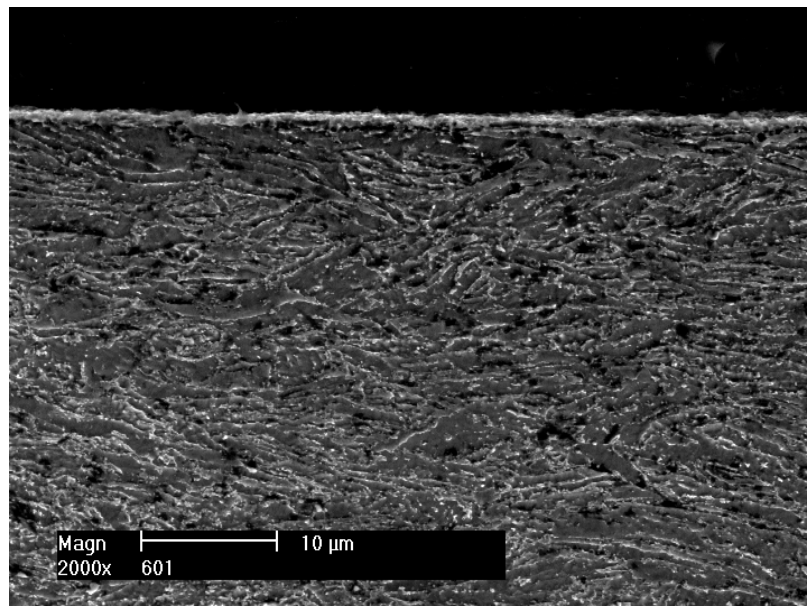

(b) H2 G92

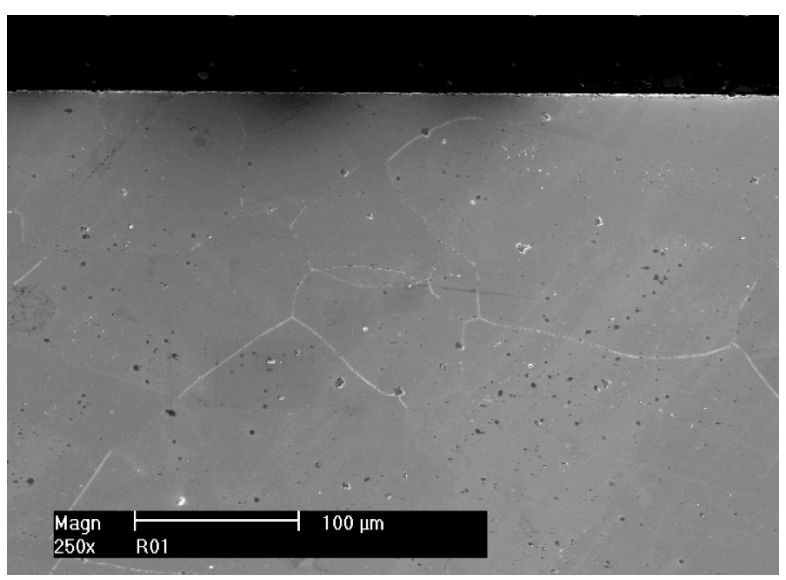

(d) HR HT-UPS

Figure. 3-4. SEM micrographs of cross-sections of specimens exposed to sodium for $2700 \mathrm{~h}$ at $550^{\circ} \mathrm{C}$. 


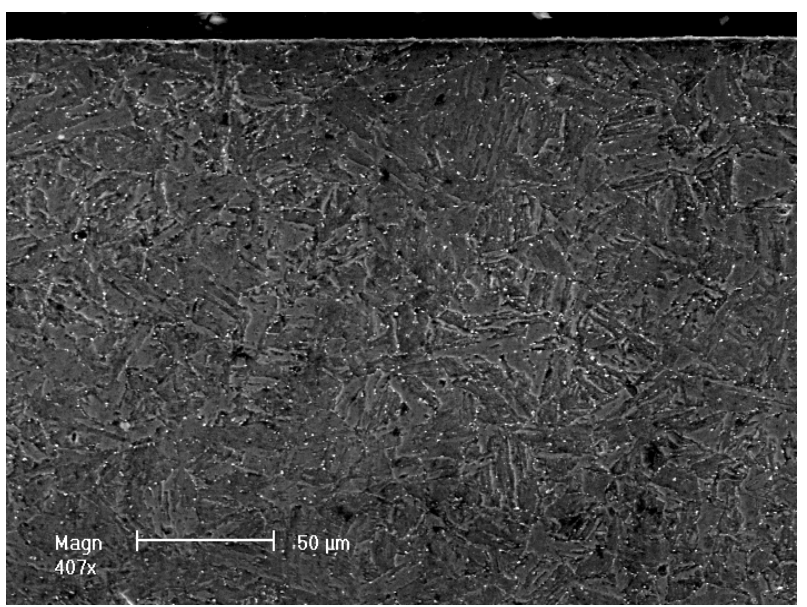

(a) H1 G92

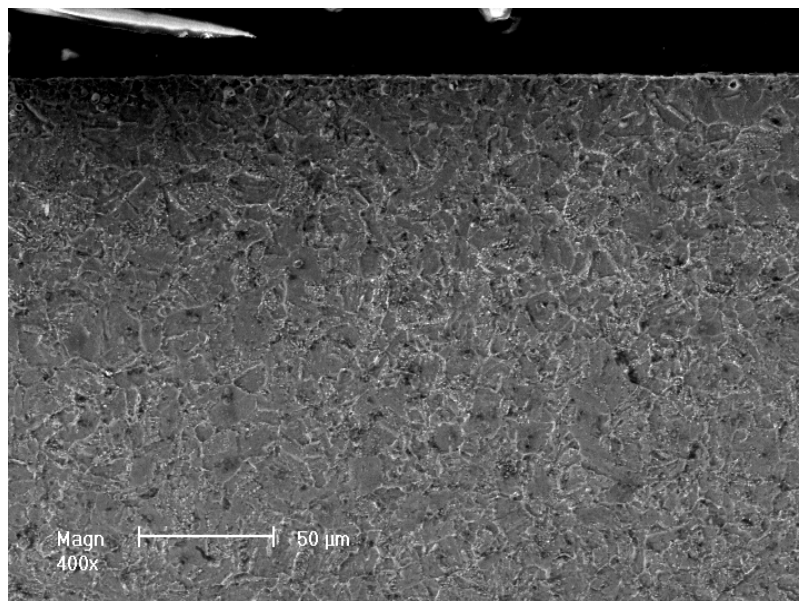

(d) G91

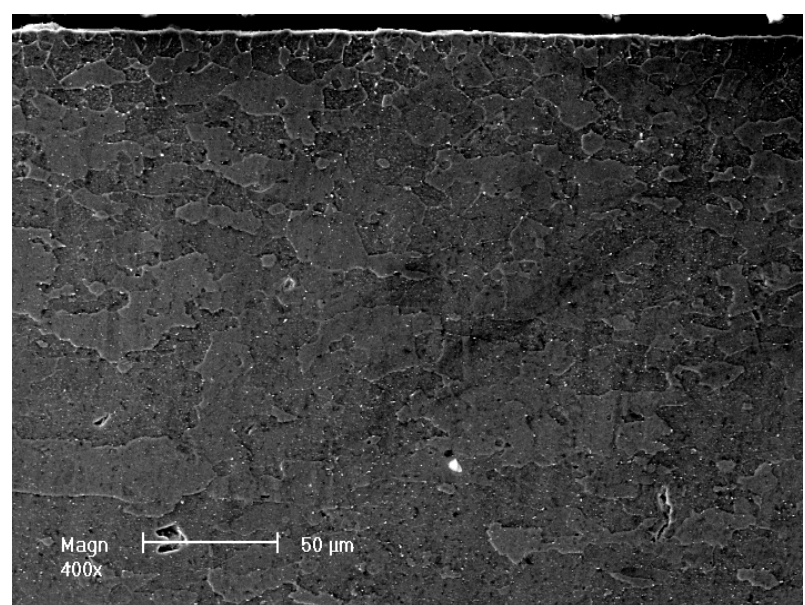

(b) H2 G92

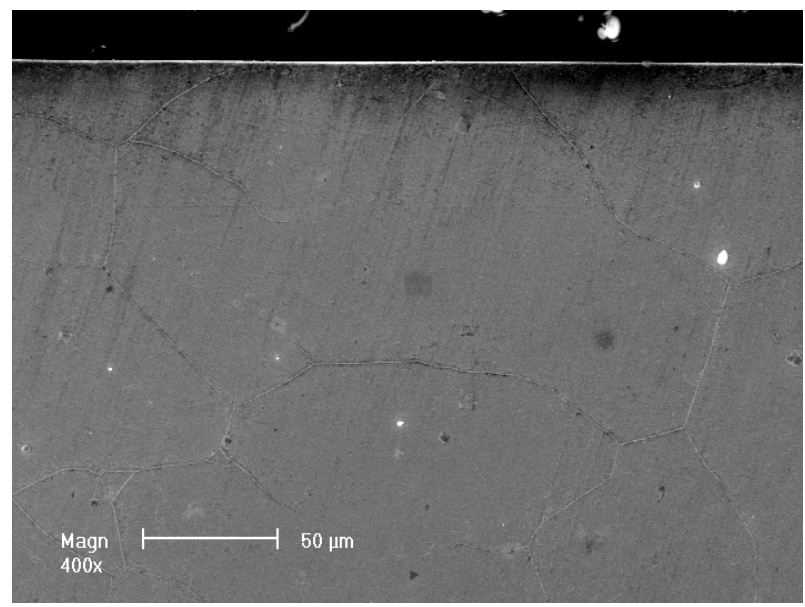

(d) HR HT-UPS

Figure. 3-5. SEM micrographs of cross-sections of specimens exposed to sodium for $3696 \mathrm{~h}$ at $650^{\circ} \mathrm{C}$. 


\subsection{Microstructure}

Figure 3-6 shows optical micrographs of H1 G92 steel (a) in the as-received condition and (b) after sodium exposure at $650^{\circ} \mathrm{C}$ for $3696 \mathrm{~h}$, respectively. No significant change in martensite structure was observed after sodium exposure for $3696 \mathrm{~h}$ at $650^{\circ} \mathrm{C}$.

Figure 3-7 shows optical micrographs of H2 G92 (a) in the as-received cold-rolled condition and (b) after sodium exposure at $650^{\circ} \mathrm{C}$ for $3696 \mathrm{~h}$, respectively. In contrast to the normalized and tempered H1 G92, the cold-rolled H2 G92 steel shows drastic microstructural changes after sodium exposure for $3696 \mathrm{~h}$ at $650^{\circ} \mathrm{C}$. The initial highly-textured martensite lath structure was transformed to elongated ferrite structure.

Figure 3-8 shows optical micrographs of the normalized and tempered G91 (a) in the asreceived condition and (b) after sodium exposure at $650^{\circ} \mathrm{C}$ for $3696 \mathrm{~h}$, respectively. Similar to normalized and tempered H1 G92 steel, no significant change in martensite structure was observed after sodium exposure for $3696 \mathrm{~h}$ at $650^{\circ} \mathrm{C}$.

Figure 3-9 shows optical micrographs of the HR HT-UPS (a) as-received specimen and (b) after sodium exposure at $650^{\circ} \mathrm{C}$ for $3696 \mathrm{~h}$, respectively. No significant change in austenite structure was observed after sodium exposure for $3696 \mathrm{~h}$ at $650^{\circ} \mathrm{C}$. It was noted that grain boundaries in sodium-exposed specimens were easy to etch relative to the as-received specimen, indicating sensitization of the steel during the sodium exposure.

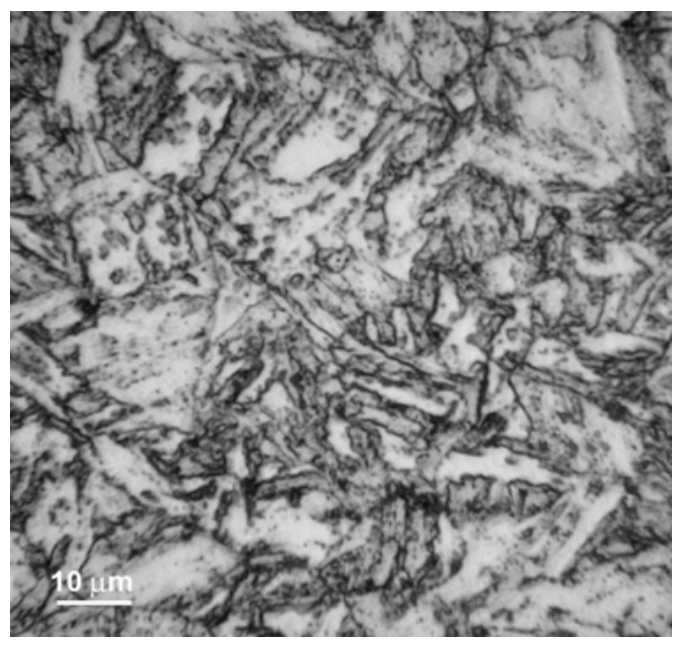

(a) As-received

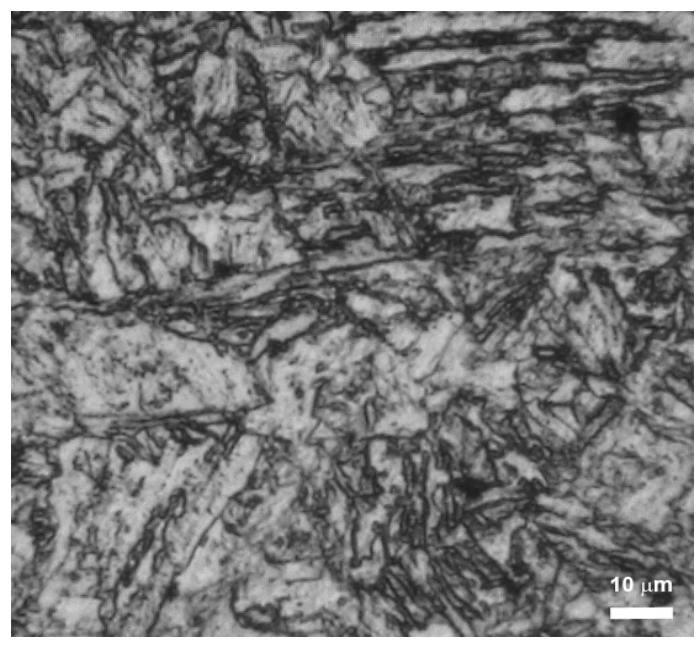

(b) After sodium exposure at $650^{\circ} \mathrm{C}$ for $3696 \mathrm{~h}$

Figure 3-6. Optical micrographs showing the microstructure of H1 G92 steel (a) in as-received condition and (b) after sodium exposure at $650^{\circ} \mathrm{C}$ for $3696 \mathrm{~h}$. 

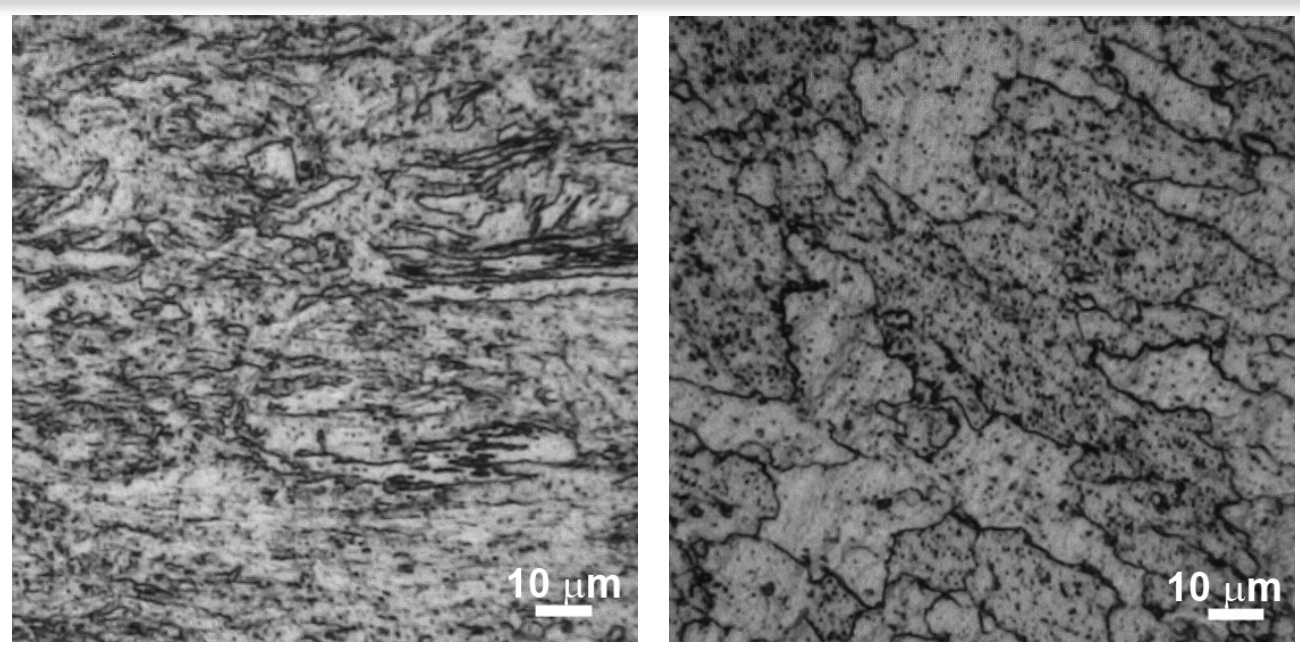

(a) As-received

(b) After sodium exposure at $650^{\circ} \mathrm{C}$ for $3696 \mathrm{~h}$

Figure 3-7. Optical micrographs showing the microstructure of H2 G92 steel (a) in as-received condition, (b) after sodium exposure for $3696 \mathrm{~h}$ at $650^{\circ} \mathrm{C}$.
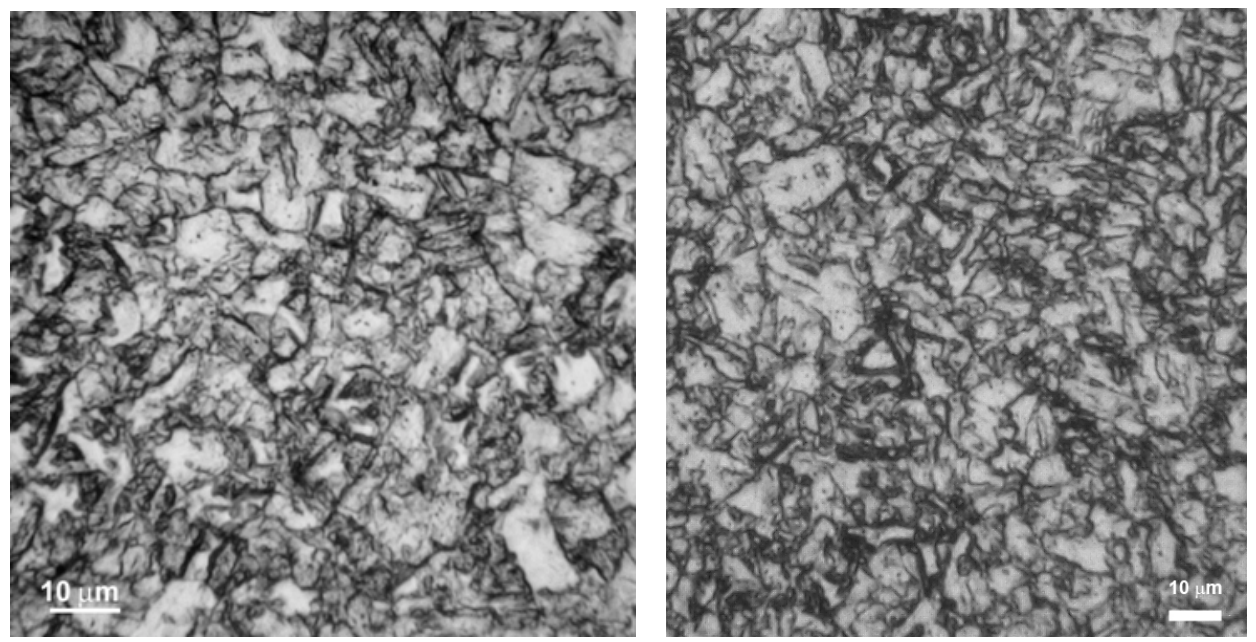

(a) As-received

(b) After sodium exposure at $650^{\circ} \mathrm{C}$ for $3696 \mathrm{~h}$

Figure 3-8. Optical micrographs showing the microstructure of G91 steel (a) in as-received condition and (b) sodium exposure for $3696 \mathrm{~h}$ at $650^{\circ} \mathrm{C}$. 

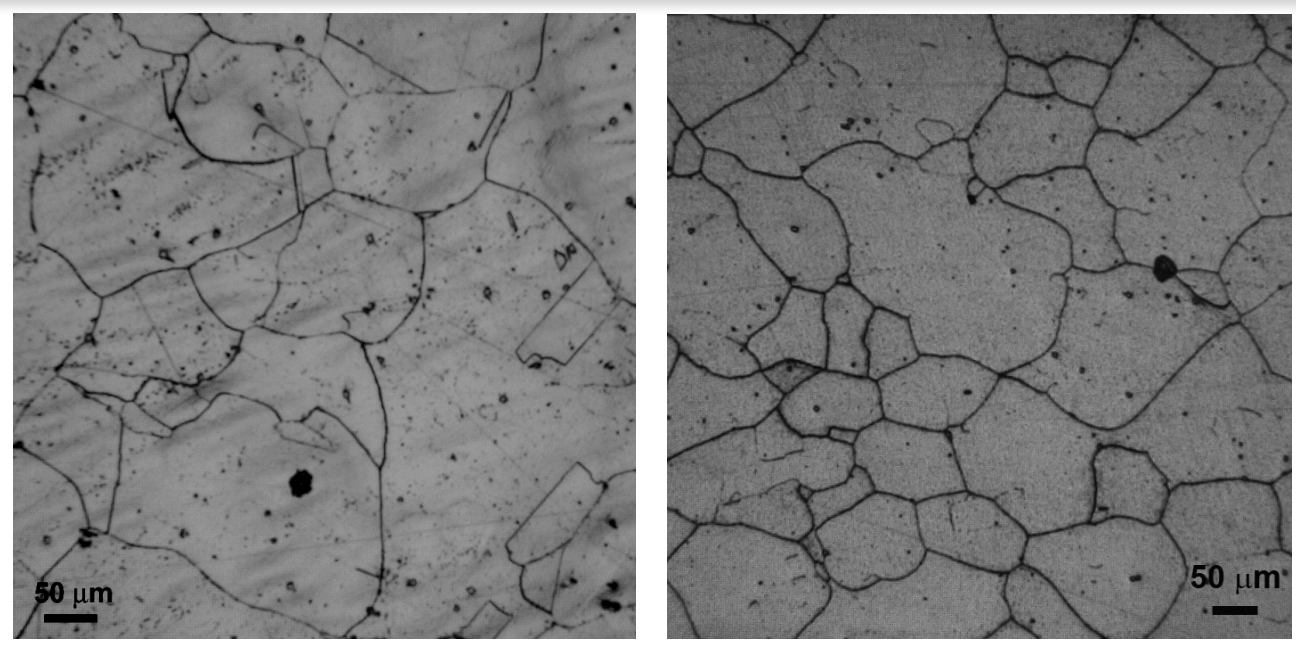

(a) As-received

(b) After sodium exposure at $650^{\circ} \mathrm{C}$ for $3696 \mathrm{~h}$

Figure 3-9. Optical micrographs showing the microstructure of HR HT-UPS (a) in as-received condition and (b) after sodium exposure for $3696 \mathrm{~h}$ at $650^{\circ} \mathrm{C}$.

Due to drastic changes in microstructure observed in the sodium-exposed specimens of $\mathrm{H} 2$ G92 steel, its structure was further examined by TEM. Figure 3-10 shows the microstructure of the cold-rolled H2 G92 steel (a) in as-received condition, (b) after sodium exposure for $2700 \mathrm{~h}$ at $550^{\circ} \mathrm{C}$, and (c) after sodium exposure for $3696 \mathrm{~h}$ at $650^{\circ} \mathrm{C}$, respectively. As shown in Fig. 310(a), the microstructure of the cold-rolled H2 G92 steel shows highly elongated martensite lath structure and high dislocation density. The diffraction ring patterns of the as-received specimen indicate strong texture in the alloy. Recrystallization occurred in H2 G92 steel after exposure to liquid sodium at $550^{\circ} \mathrm{C}$ for $2700 \mathrm{~h}$. Sub-micron grains, free of dislocations, formed as shown in Fig. 3-10(b). After exposure to sodium for $3696 \mathrm{~h}$ at $650^{\circ} \mathrm{C}$, martensite transformed completely to ferrite with large grain size, as shown in Fig. 3-10(c). The diffraction pattern showed individual spots in contrast to the ring patterns shown in Figs. 3-10(a) and (b). A high number density of precipitate particles formed within a grain with extremely low density of dislocation segments. The TEM observation shown in Fig. 3-10(c) is consistent with the metallographic result shown in Fig. 3-7. It is apparent that the large strain energy stored in the alloy due to cold rolling significantly reduced the recrystallization temperature, and affected the precipitation kinetics. Further analysis is needed to differentiate the thermal aging effect from the effect of sodium exposure. 

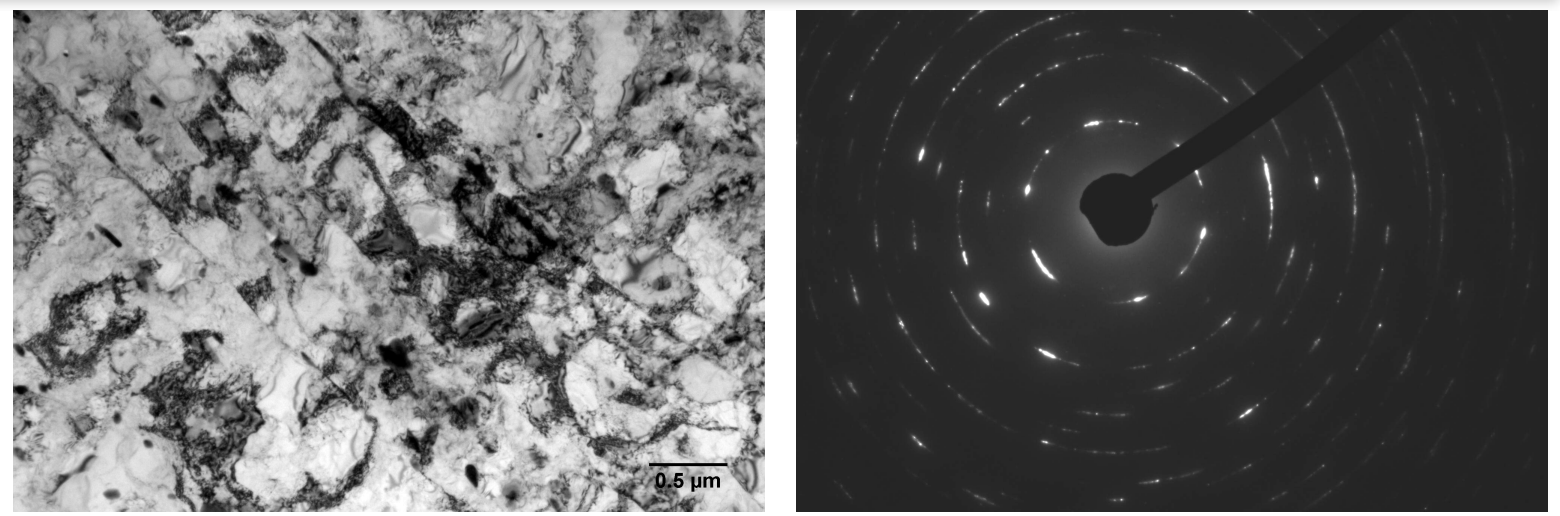

(a) As-received
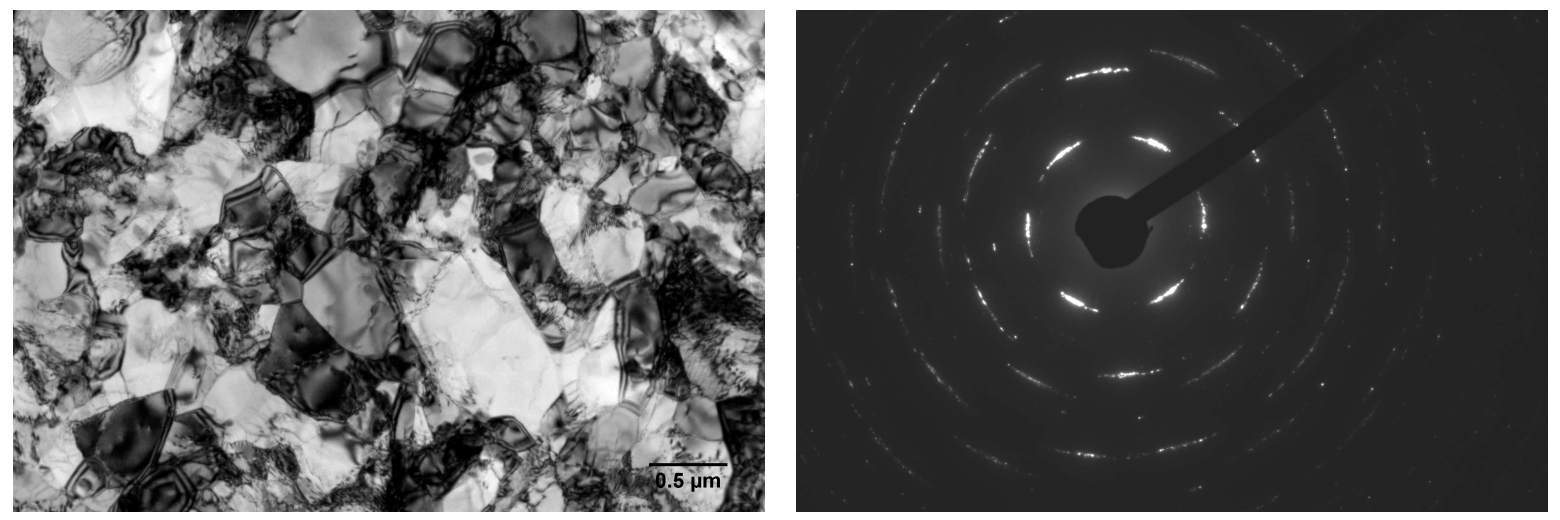

(b) After exposure at $550^{\circ} \mathrm{C}$ for $2700 \mathrm{~h}$ in sodium
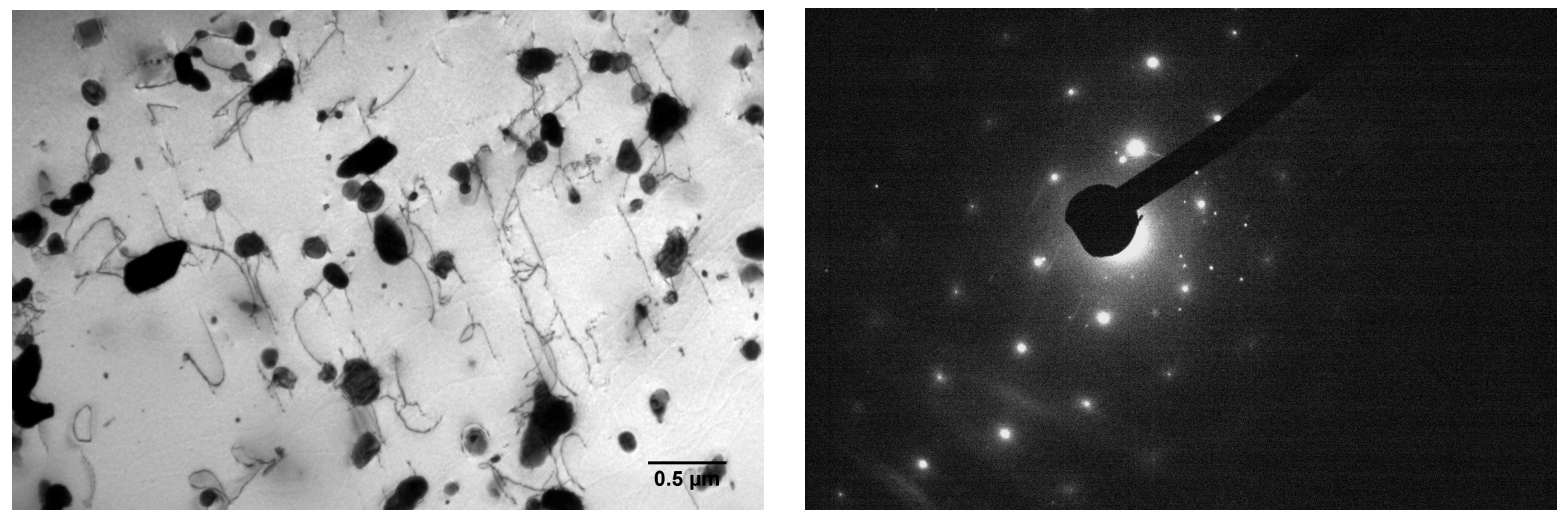

(c) After exposure at $650^{\circ} \mathrm{C}$ for $3696 \mathrm{~h}$ in sodium

Figure 3-10. TEM images showing microstructures of H2 G92 steel (a) in as-received cold-rolled condition, (b) after exposure to sodium at $550^{\circ} \mathrm{C}$ for $2700 \mathrm{~h}$, and (c) after exposure to sodium at $650^{\circ} \mathrm{C}$ for $3696 \mathrm{~h}$. 


\subsection{Tensile Behavior}

The engineering stress-strain curves of the as-received and $550^{\circ} \mathrm{C}-2700 \mathrm{~h}$ sodium-exposed specimens for $\mathrm{H} 1 \mathrm{G} 92$ steel tested at $550^{\circ} \mathrm{C}$ are given in Fig. 3-11. Note that the temperature of a tensile test was the same as the sodium exposure temperature. No effect of sodium exposure on the yield stress and ultimate tensile strength was observed. Both specimens showed similar tensile behavior with limited strain hardening and uniform elongations at $550^{\circ} \mathrm{C}$.

Figure 3-12 shows the stress-strain curves of the as-received and $650^{\circ} \mathrm{C}-3696 \mathrm{~h}$ sodiumexposed specimens for $\mathrm{H} 1 \mathrm{G} 92$ steel tested at $650^{\circ} \mathrm{C}$. The tensile strength of $\mathrm{H} 2 \mathrm{G} 92$ steel was significantly reduced after sodium exposure for $3696 \mathrm{~h}$ at $650^{\circ} \mathrm{C}$. The ultimate tensile strength of the sodium-exposed specimen is $226 \mathrm{MPa}, \sim 30 \%$ below the value of the as-received specimen. The microstructure observed by optical microscopy showed no changes in martensite structure of the sodium-exposed specimen, implying that the strength reduction from the sodium exposure may be associated with second-phase precipitates, e.g. carbides, carbonitrides in H1 G92. Further microstructural analysis by electron microscopy and synchrotron radiation will provide critical information to understand the effect of sodium exposure on mechanical properties.

Figure 3-13 shows the stress-strain curves of the as-received and $550^{\circ} \mathrm{C}-2700 \mathrm{~h}$ sodiumexposed specimens for $\mathrm{H} 2 \mathrm{G} 92$ steel tested at $550^{\circ} \mathrm{C}$. Similar to the $\mathrm{H} 1 \mathrm{G} 92$ steel, no significant effect of sodium exposure on tensile strength was observed at $550^{\circ} \mathrm{C}$. The sodium-exposed specimen showed a relatively lower total elongation relative to the as-received specimen. TEM observation of the $550^{\circ} \mathrm{C}-2700 \mathrm{~h}$ sodium-exposed specimen showed recrystallization and formation of fine grains, which apparently has no significant influence on tensile properties.

The engineering stress-strain curves of as-received and sodium-exposed specimens, $650^{\circ} \mathrm{C}$ $1368 \mathrm{~h}$ and $650^{\circ} \mathrm{C}-3696 \mathrm{~h}$ for $\mathrm{H} 2 \mathrm{G} 92$ steel tested at $650^{\circ} \mathrm{C}$ are given in Fig. 3-14. A drastic reduction of tensile strength was observed after sodium exposure even for $1368 \mathrm{~h}$ at $650^{\circ} \mathrm{C}$. The ultimate tensile strength of the $650^{\circ} \mathrm{C}-1368 \mathrm{~h}$ is about half of the value of the as-received specimen. The strength continued to decrease up to $3696 \mathrm{~h}$ sodium exposure. Strength reduction was accompanied by an increase in the uniform elongation. The sodium-exposed specimens showed a considerable strain softening effect. The total elongation of the sodium-exposed specimens is significantly larger than the as-received specimen. Microstructural analysis showed dramatic recovery and grain growth after sodium exposure at $650^{\circ} \mathrm{C}$, consistent with the tensile property measurements.

Figure 3-15 shows the stress-strain curves of G91 steel in the as-received condition and after sodium exposure for $2700 \mathrm{~h}$ at $550^{\circ} \mathrm{C}$. No obvious changes in tensile behavior were observed after sodium exposure for $2700 \mathrm{~h}$ at $550^{\circ} \mathrm{C}$.

The stress-strain curves of the as-received specimen and the sodium-exposed specimen, $650^{\circ} \mathrm{C}-1368 \mathrm{~h}, 650^{\circ} \mathrm{C}-3696 \mathrm{~h}$ and $650^{\circ} \mathrm{C}-5064 \mathrm{~h}$ for $\mathrm{G} 91$ steel tested at $650^{\circ} \mathrm{C}$ are given in Fig. 3-16. The tensile strength of G91 steel was dramatically reduced after sodium exposure for only $1368 \mathrm{~h}$ at $650^{\circ} \mathrm{C}$. The ultimate tensile strength of the $650^{\circ} \mathrm{C}-1368 \mathrm{~h}$ sodium-exposed specimen is 
$170 \mathrm{MPa}$, compared to $269 \mathrm{MPa}$ in the as-received condition. Exposure for $5064 \mathrm{~h}$ further reduced the tensile strength of G91 steel. The reduction in tensile strength is accompanied by recovery of the uniform elongation. The sodium-exposed specimens showed similar strain softening behavior to the as-received specimen.

The stress-strain curves of HR HT-UPS steel in the as-received condition and after sodium exposure for $2700 \mathrm{~h}$ at $550^{\circ} \mathrm{C}$ and tensile-tested at $550^{\circ} \mathrm{C}$ are shown in Fig. 3-17. Similar to the observations in G92 and G91 ferritic-martensitic steels, sodium exposure at $550^{\circ} \mathrm{C}$ for $2700 \mathrm{~h}$ had minimal effect on tensile behavior of HR HT-UPS steel.

The stress-strain curves of the as-received specimen and the sodium-exposed specimen, $650^{\circ} \mathrm{C}-1368 \mathrm{~h}, 650^{\circ} \mathrm{C}-3696 \mathrm{~h}$ and $650^{\circ} \mathrm{C}-5064 \mathrm{~h}$ for HR HT-UPS steel tested at $650^{\circ} \mathrm{C}$ are given in Fig. 3-18. All three sodium-exposed specimens show similar tensile behavior. Compared with the as-received specimen, the sodium-exposed specimens showed a higher yield stress and a lower ultimate tensile stress. The total elongation of the sodium-exposed specimens is significantly lower than that of the as-received specimen. The higher yield stress of the sodiumexposed specimens may be explained by the precipitation of second-phases in the matrix, and the lower elongation may be due to grain boundary precipitation, observed in the thermally-aged specimens [ $\mathrm{Li}$ et al. 2011], though TEM characterization of the sodium-exposed specimens is needed to determine the microstructural changes of the sodium exposure effect. It was also noted that the stress-strain curve of the as-received specimen tested at 550 and $650^{\circ} \mathrm{C}$ showed pronounced serrations, an indication of dynamic strain aging, often observed in austenitic stainless steel. Sodium exposures, particularly at $650^{\circ} \mathrm{C}$, significantly reduced the serrations of the flow curves.

Table 3-1 summarizes the tensile properties including yield stress (YS), ultimate tensile strength (UTS), uniform elongation (UE), and total elongation (TE), of the as-received and sodium-exposed specimens for H1 G92, H2 G92, G91 ferritic-martensitic steels, and HR HTUPS austenitic stainless steel. 


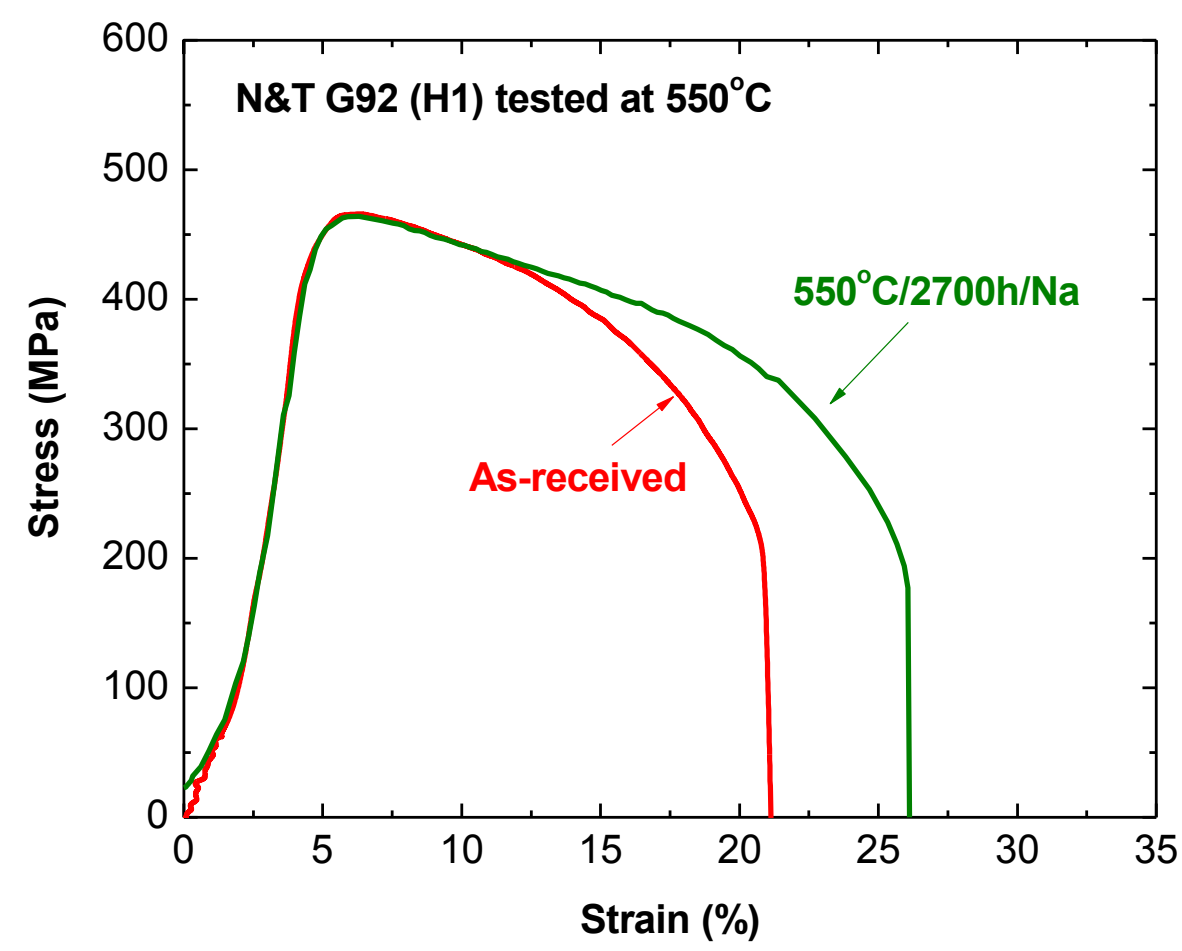

Figure 3-11. Stressstrain curves of H1 G92 in the as-received condition and after 2700-h sodium exposure at $550^{\circ} \mathrm{C}$.

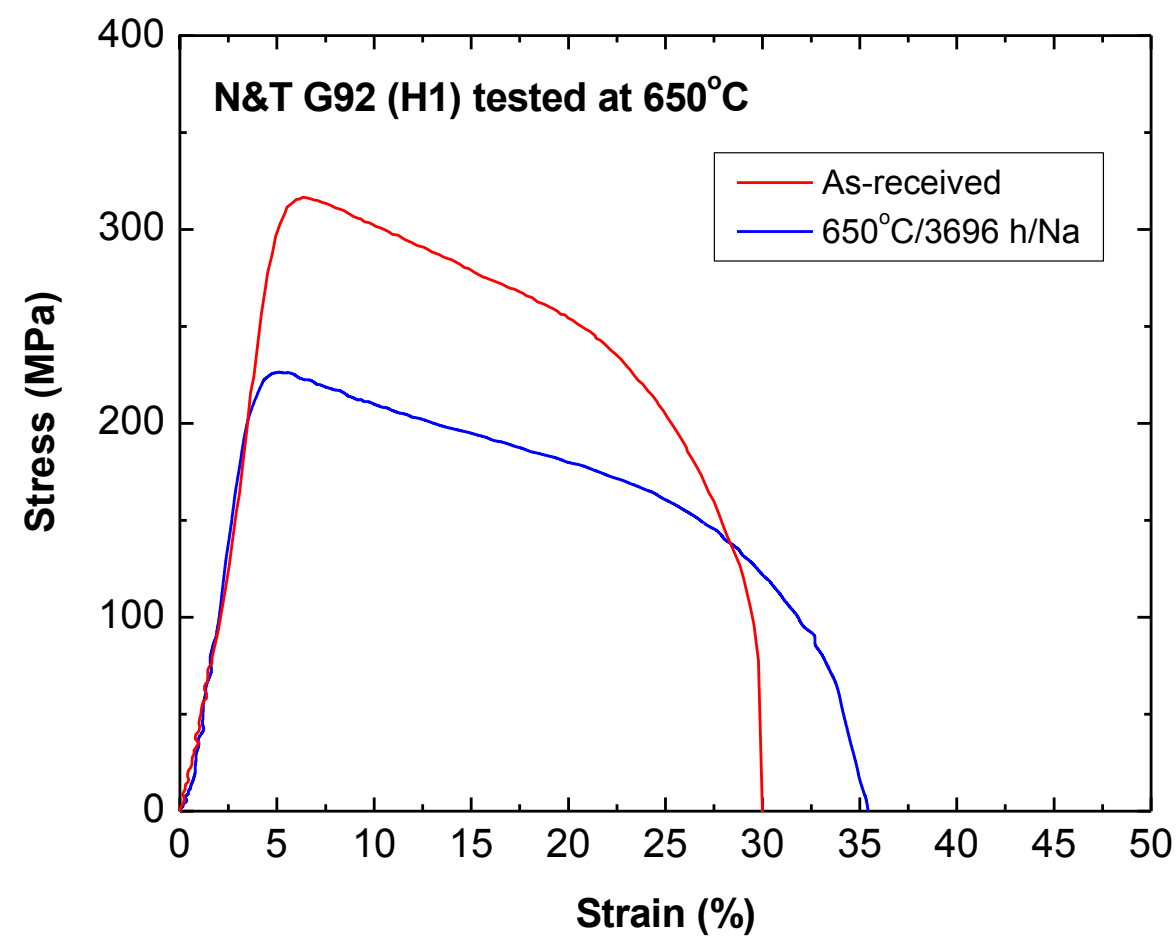

Figure 3-12. Stressstrain curves of H1 G92 in the as-received condition and after 3696-h sodium exposure at $650^{\circ} \mathrm{C}$. 


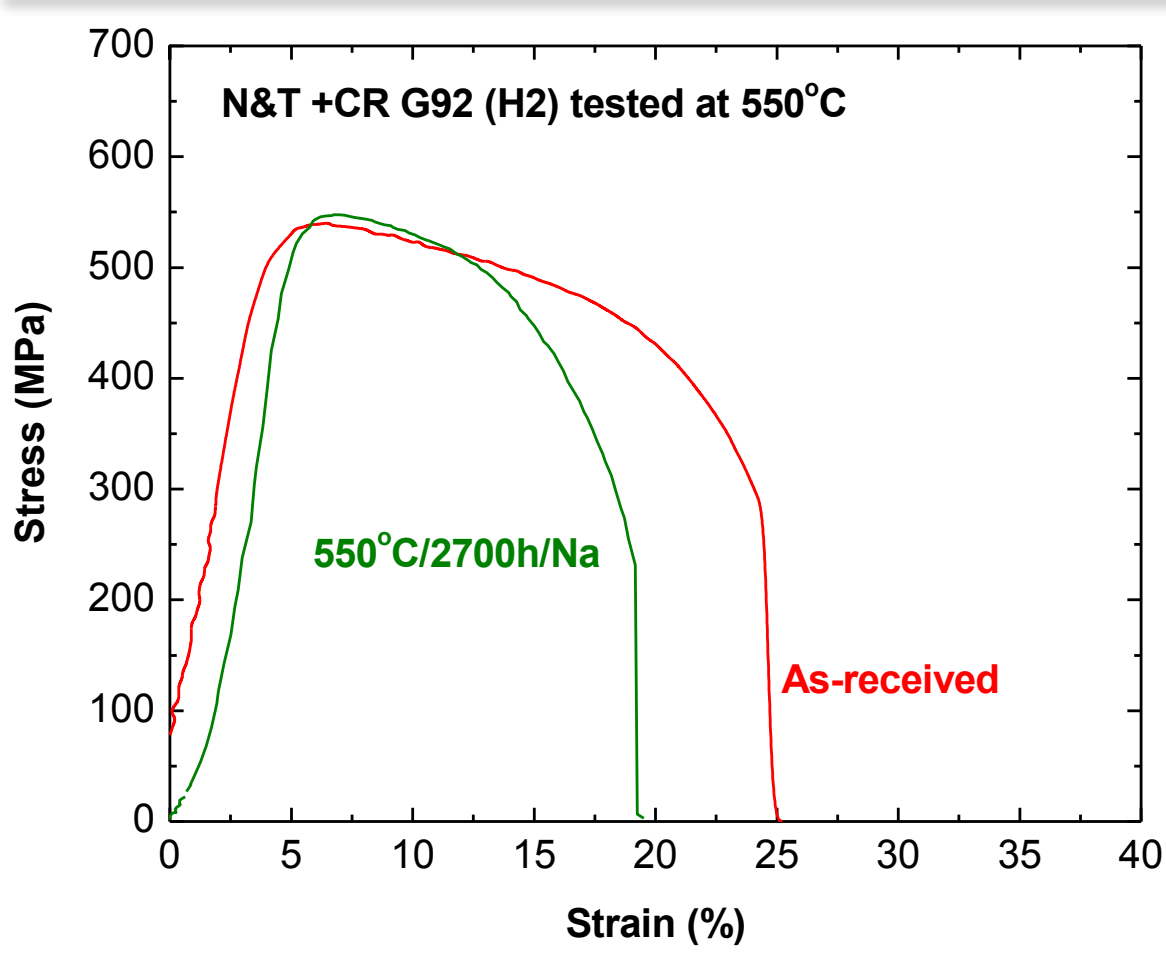

Figure 3-13. Stressstrain curves of $\mathrm{H} 2 \mathrm{G} 92$ in the as-received condition and after 2700-h sodium exposure at $550^{\circ} \mathrm{C}$.

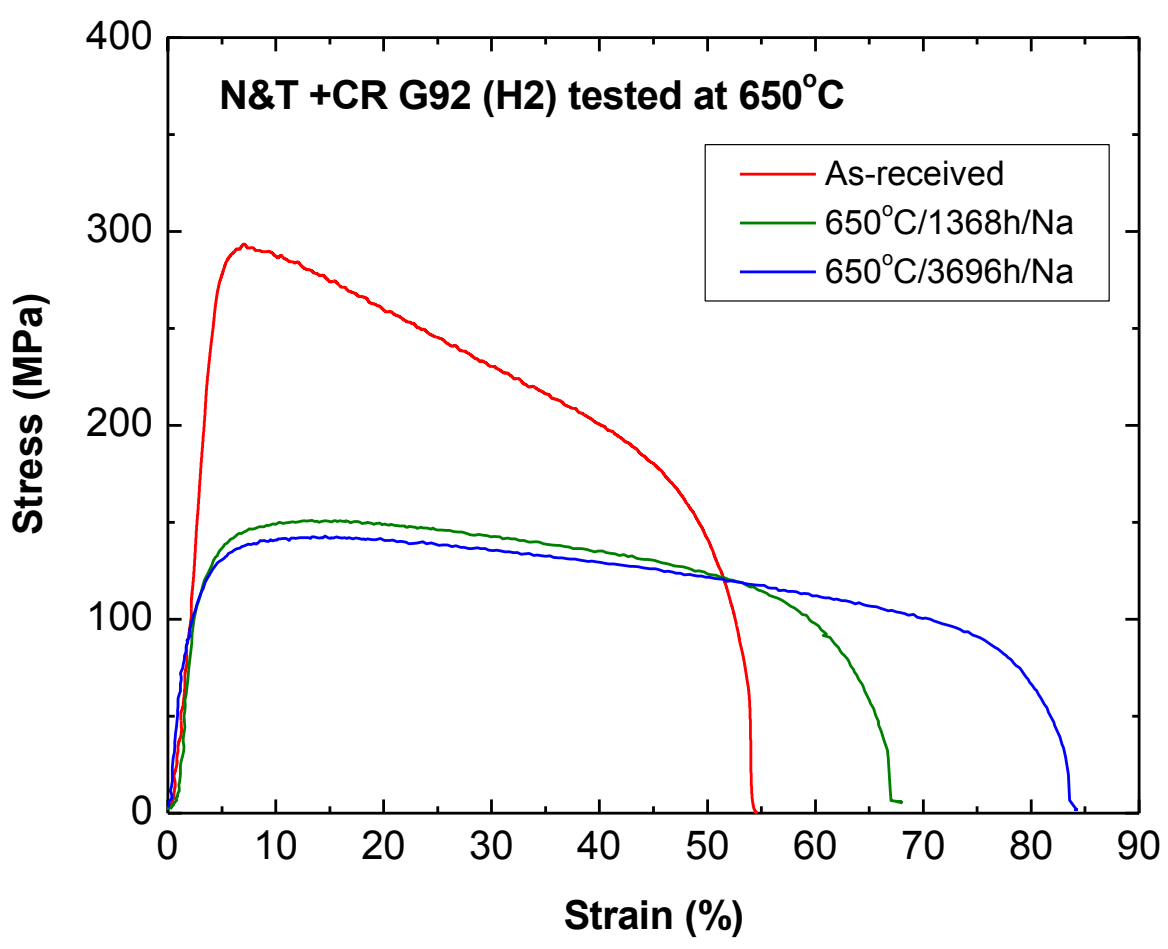

Figure 3-14. Stressstrain curves of $\mathrm{H} 2 \mathrm{G} 92$ in the as-received condition and after sodium exposure at $650^{\circ} \mathrm{C}$. 


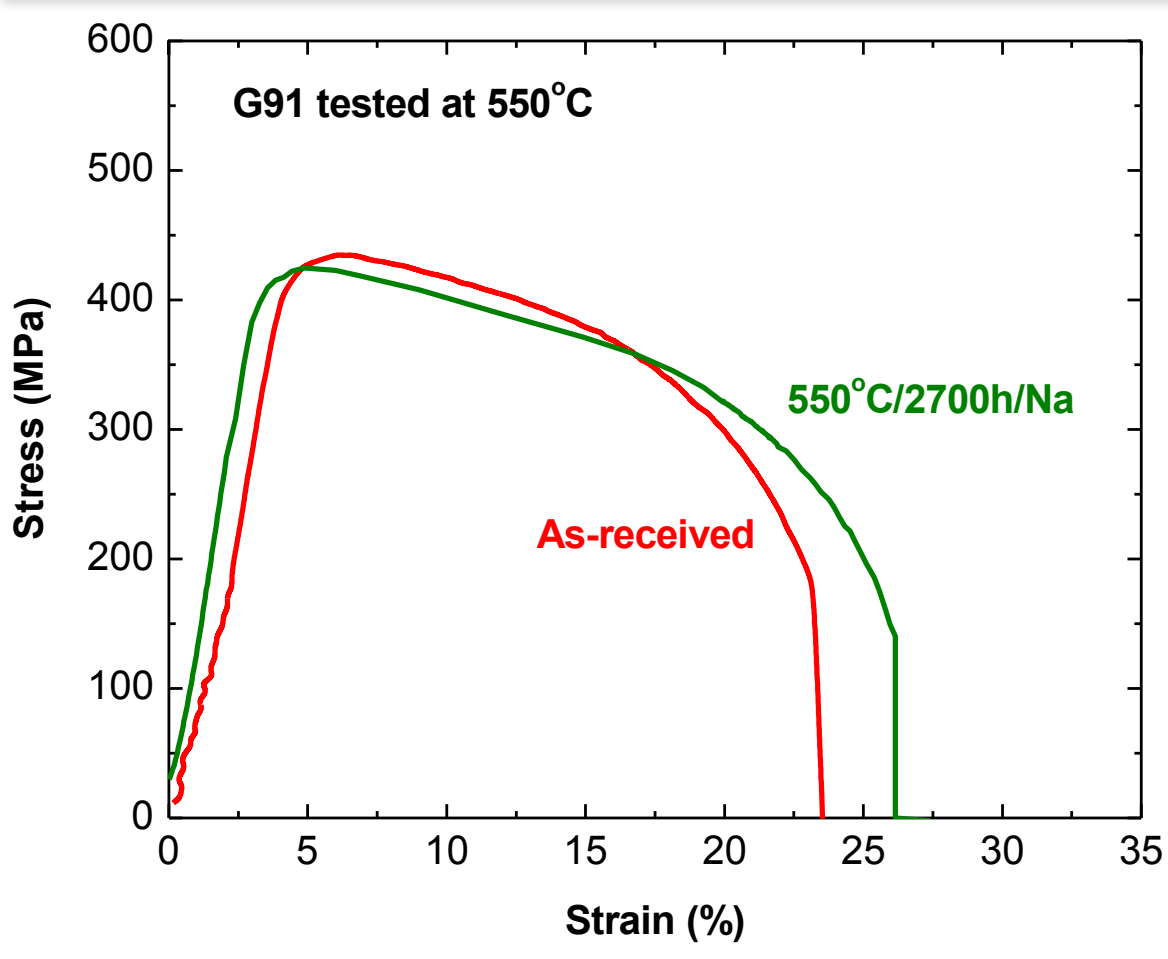

Figure 3-15. Stressstrain curves of G91 in the as-received condition and after 2700-h sodium exposure at $550^{\circ} \mathrm{C}$.

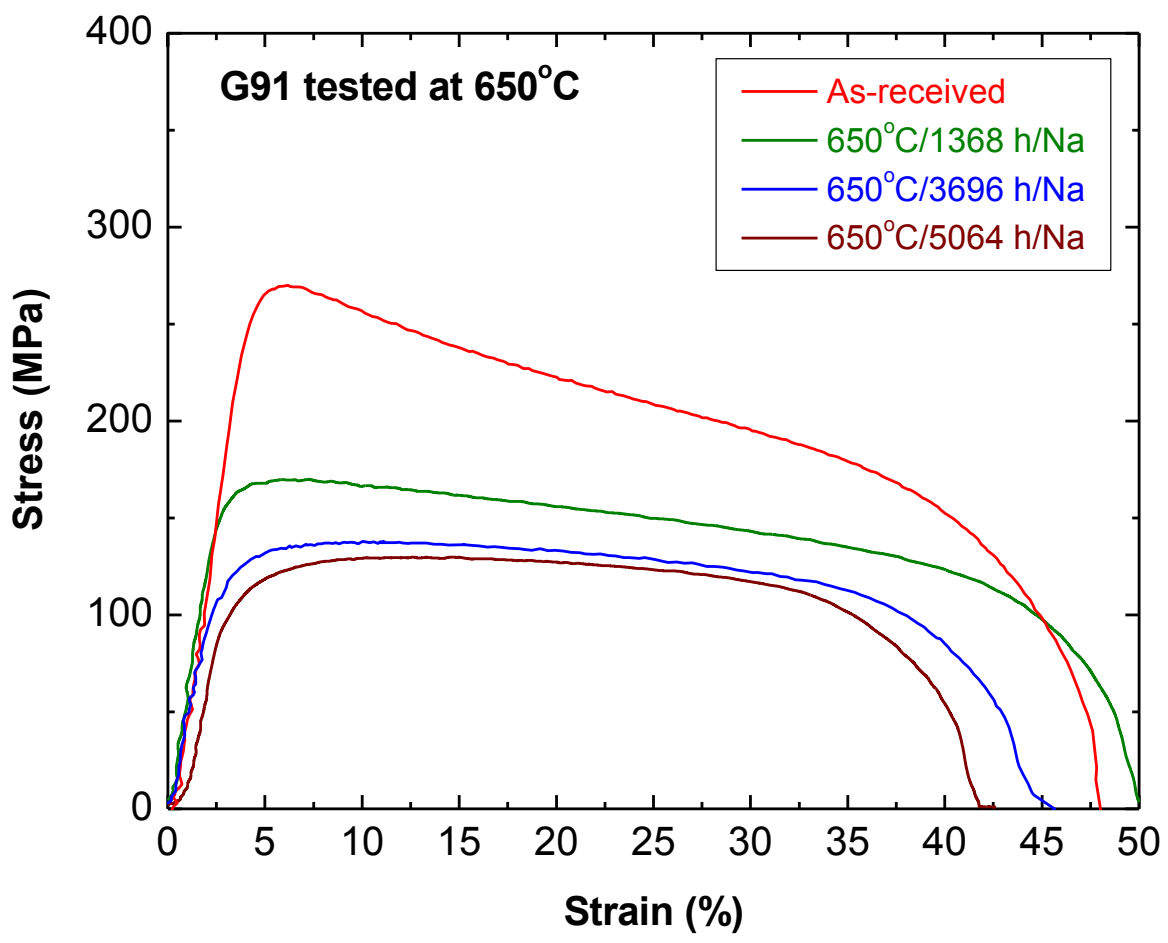

Figure 3-16. Stressstrain curves of G91 in the as-received condition and after sodium exposure at $650^{\circ} \mathrm{C}$. 


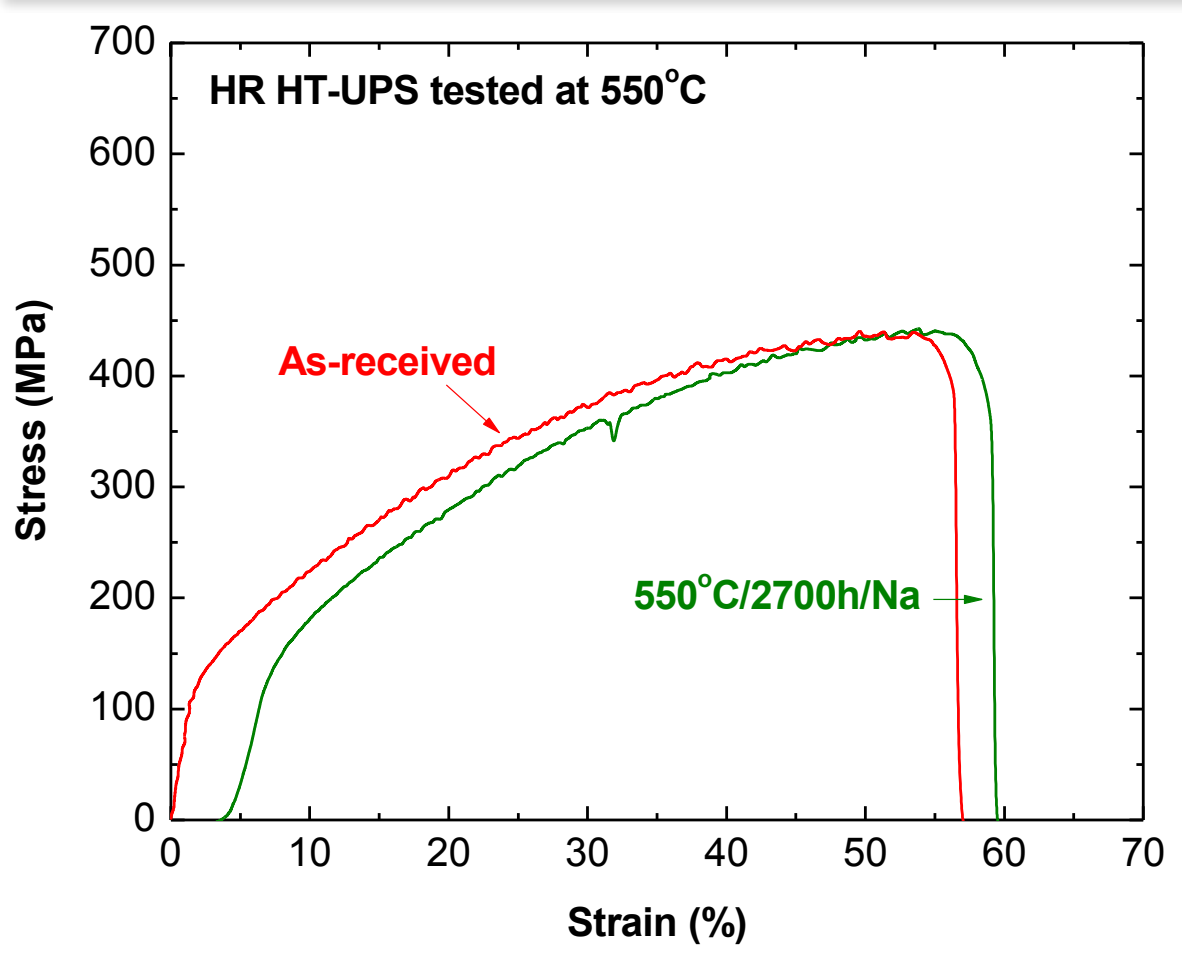

Figure 3-17. Stressstrain curves of HR HTUPS in the as-received condition and after 2700-h sodium exposure at $550^{\circ} \mathrm{C}$.

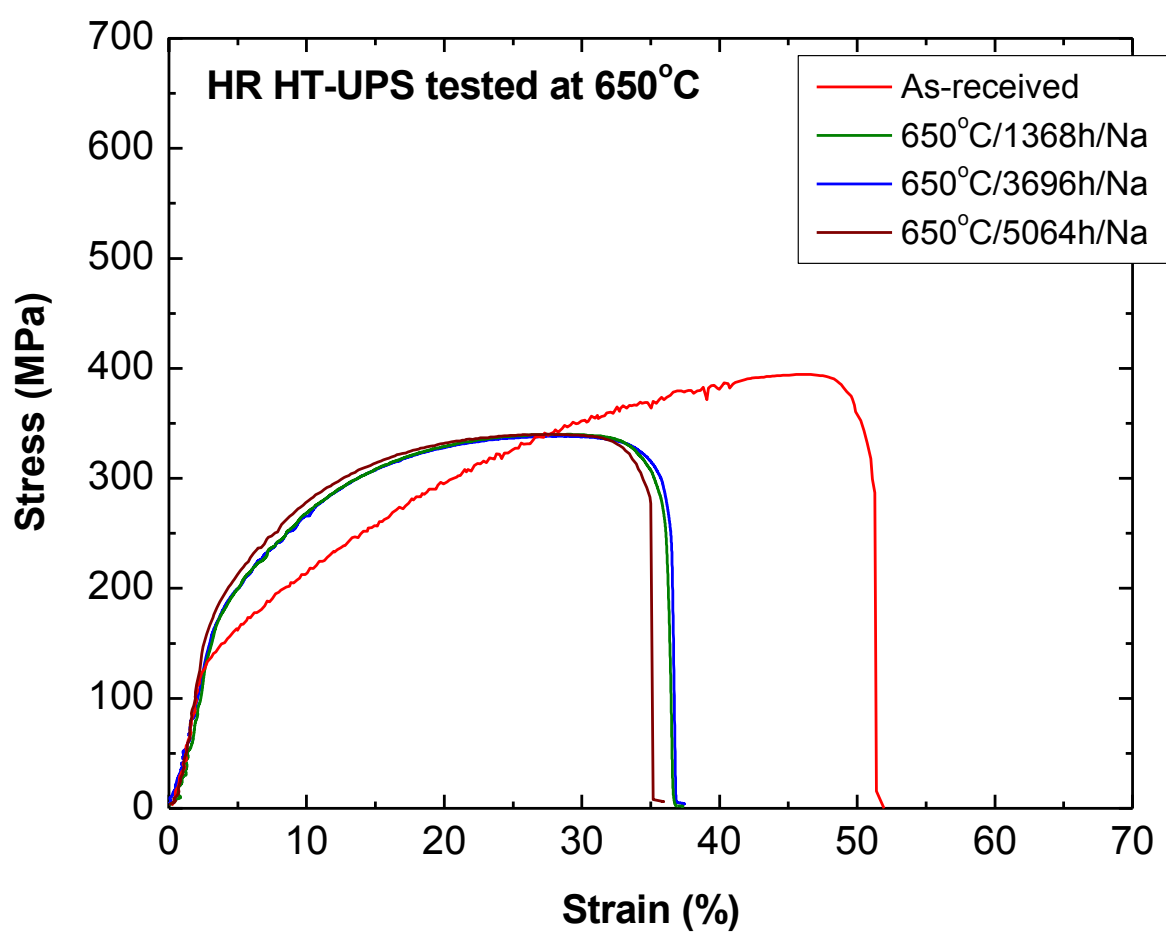

Figure 3-18. Stressstrain curves of HR HTUPS in the as-received condition and after sodium exposure at $650^{\circ} \mathrm{C}$. 
Table 3-1. Effects of sodium exposure on tensile properties.

\begin{tabular}{|c|c|c|c|c|c|c|c|}
\hline Alloy & Specimen Condition & Test T $\left({ }^{\circ} \mathrm{C}\right)$ & Strain Rate $\left(\mathrm{s}^{-1}\right)$ & YS (MPa) & UTS (MPa) & UE $(\%)$ & $\mathrm{TE}(\%)$ \\
\hline G91 & As Received & 550 & 0.001 & 406 & 435 & 2.3 & 20 \\
\hline G91 & $550^{\circ} \mathrm{C} / 2700 \mathrm{~h} \mathrm{Na}$ & 550 & 0.001 & 394 & 425 & 1.7 & 25 \\
\hline G91 & As Received & 650 & 0.001 & 237 & 269 & 2.6 & 46.5 \\
\hline G91 & $650^{\circ} \mathrm{C} / 1368 \mathrm{~h} \mathrm{Na}$ & 650 & 0.001 & 146 & 170 & 3 & 48 \\
\hline G91 & $650^{\circ} \mathrm{C} / 3696 \mathrm{~h} \mathrm{Na}$ & 650 & 0.001 & 104 & 138 & 7 & 42 \\
\hline G91 & $650^{\circ} \mathrm{C} / 5064 \mathrm{~h} \mathrm{Na}$ & 650 & 0.001 & 96 & 130 & 9 & 39 \\
\hline H1 NF616 & As Received & 550 & 0.001 & 443 & 465 & 1.7 & 18 \\
\hline H1 NF616 & $550^{\circ} \mathrm{C} / 2700 \mathrm{~h} \mathrm{Na}$ & 550 & 0.001 & 447 & 464 & 1.5 & 23 \\
\hline H1 NF616 & As Received & 650 & 0.001 & 295 & 315 & 1.7 & 28 \\
\hline H1 NF616 & $650^{\circ} \mathrm{C} / 3696 \mathrm{~h} \mathrm{Na}$ & 650 & 0.001 & 211 & 226 & 1.5 & 31 \\
\hline H2 NF616 & As Received and CR & 550 & 0.001 & 505 & 541 & 2 & 22.7 \\
\hline H2 NF616 & $550^{\circ} \mathrm{C} / 2700 \mathrm{~h} \mathrm{Na}$ & 550 & 0.001 & 523 & 548 & 2 & 16 \\
\hline H2 NF616 & As Received and CR & 650 & 0.001 & 274 & 294 & 2 & 52 \\
\hline H2 NF616 & $650^{\circ} \mathrm{C} / 1368 \mathrm{~h} \mathrm{Na}$ & 650 & 0.001 & 106 & 151 & 11 & 65 \\
\hline H2 NF616 & $650^{\circ} \mathrm{C} / 3696 \mathrm{~h} \mathrm{Na}$ & 650 & 0.001 & 86 & 142 & 12 & 82 \\
\hline HR HT-UPS & As Received & 550 & 0.001 & 118 & 440 & 47 & 51 \\
\hline HR HT-UPS & $550^{\circ} \mathrm{C} / 2700 \mathrm{~h} \mathrm{Na}$ & 550 & 0.001 & 143 & 448 & 40 & 47 \\
\hline HR HT-UPS & As Received & 650 & 0.001 & 129 & 394 & 40 & 46 \\
\hline HR HT-UPS & $650^{\circ} \mathrm{C} / 1368 \mathrm{~h} \mathrm{Na}$ & 650 & 0.001 & 175 & 340 & 22 & 31 \\
\hline HR HT-UPS & $650^{\circ} \mathrm{C} / 3696 \mathrm{~h} \mathrm{Na}$ & 650 & 0.001 & 175 & 338 & 22 & 31 \\
\hline HR HT-UPS & $650^{\circ} \mathrm{C} / 5064 \mathrm{~h} \mathrm{Na}$ & 650 & 0.001 & 168 & 340 & 23 & 30.5 \\
\hline
\end{tabular}




\section{Summary}

This report presents the results on corrosion performance, microstructure, and tensile properties of advanced ferritic-martensitic and austenitic alloys exposed to liquid sodium at $550^{\circ} \mathrm{C}$ for up to $2700 \mathrm{~h}$ and at $650^{\circ} \mathrm{C}$ for up to $5064 \mathrm{~h}$ in the forced convection sodium loop. The oxygen content of sodium was controlled by the cold-trapping method to achieve $\sim 1$ wppm oxygen level. Four alloys were examined, G92 in the normalized and tempered condition (H1 G92), G92 in the cold-rolled condition (H2 G92), G91 in the normalized and tempered condition, and hot-rolled HT-UPS. G91 was included as a reference to compare with advanced alloy, G92.

All four alloys exhibited weight loss after sodium exposures at $550^{\circ} \mathrm{C}$ and $650^{\circ} \mathrm{C}$. The weight loss of the four alloys was comparable after sodium exposures at $550^{\circ} \mathrm{C}$; the weight loss of ferritic-martensitic steels, G92 and G91 is more significant than that of austenitic stainless steel, HT-UPS after sodium exposures at $650^{\circ} \mathrm{C}$. Sodium exposures for times up to $2700 \mathrm{~h}$ at $550^{\circ} \mathrm{C}$ had no significant influence on tensile properties, while sodium exposures for times up to $5064 \mathrm{~h}$ at $650^{\circ} \mathrm{C}$ dramatically changed the tensile strengths of the four alloys. The ultimate tensile strength of H1 G92, H2 G92, and G91 ferritic-martensitic steels was reduced as much as nearly half of its initial value after sodium exposures at $650^{\circ} \mathrm{C}$. Though the uniform elongation was recovered to some extent, these three ferritic-martensitic steels showed considerable strain softening after sodium exposures. The yield stress of HT-UPS austenitic stainless steel increased, the ultimate tensile strength decreased, and the total elongation was reduced after sodium exposures at $650^{\circ} \mathrm{C}$. The dynamic strain aging effect observed in the as-received HT-UPS specimens became less pronounced after sodium exposures at $650^{\circ} \mathrm{C}$. Microstructural characterization of sodium-exposed specimens showed no appreciable surface deterioration or grain structure changes under an optical microscope, except the H2 G92 steel, in which the martensite structure was completely recovered and significant grain growth occurred after sodium exposures at $650^{\circ} \mathrm{C}$. TEM observations of the sodium-exposed H2 G92 steel showed significant recrystallization after sodium exposure for $2700 \mathrm{~h}$ at $550^{\circ} \mathrm{C}$, and transformation of martensite to ferrite and high density of precipitates in nearly dislocation-free matrix after sodium exposures at $650^{\circ} \mathrm{C}$. Further microstructural analysis and evaluation of decarburization/carburization behavior is needed to understand the dramatic changes in tensile strengths of the advanced ferritic-martensitic and austenitic steels after relatively short sodium exposures at $650^{\circ} \mathrm{C}$.

\section{Acknowledgement}

Materials were provided by the Oak Ridge National Laboratory. Work was supported by the U.S. Department of Energy, Office of Nuclear Energy under Contract DE-AC02$06 \mathrm{CH} 11357$. 


\section{References}

Busby, J., T. S. Byun, R. Klueh, P. Maziasz, and J. Vitek, K. Natesan, M. Li, R. Wright, S. Maloy, M. Toloczko, A. Motta, B.D. Wirth, G. R. Odette, T. Allen, "Candidate Developmental Alloys for Improved Structural Materials for Advanced Fast Reactors," ORNL/GNEP/LTR-2008-023, March 2008.

Natesan, K. and M. Li, ANL-AFCI-270, Argonne National Laboratory, August 2009.

Natesan, K., M. Li, Y. Momozaki, and D. L. Rink, ANL-AFCI-276, Argonne National Laboratory, September 2009.

Natesan, K., Y. Momozaki, M. Li, and D. L. Rink, ANL-GenIV-163, Argonne National Laboratory, September 2010. 



\section{Argonne}

Nuclear Engineering Division

Argonne National Laboratory

9700 South Case Avenue

Argonne, IL 60439

www.anl.gov 